\title{
Juvenile Crime and Criminal Justice: Resolving Border Disputes
}

\section{Jeffrey Fagan}

\section{Summary}

Rising juvenile crime rates during the 1970s and 1980s spurred state legislatures across the country to exclude or transfer a significant share of offenders under the age of eighteen to the jurisdiction of the criminal court, essentially redrawing the boundary between the juvenile and adult justice systems. Jeffrey Fagan examines the legal architecture of the new boundarydrawing regime and how effective it has been in reducing crime.

The juvenile court, Fagan emphasizes, has always had the power to transfer juveniles to the criminal court. Transfer decisions were made individually by judges who weighed the competing interests of public safety and the possibility of rehabilitating young offenders. This authority has now been usurped by legislators and prosecutors. The recent changes in state law have moved large numbers of juveniles into the adult system. As many as 25 percent of all juvenile offenders younger than eighteen, says Fagan, are now prosecuted in adult court. Many live in states where the age boundary between juvenile and criminal court has been lowered to sixteen or seventeen.

The key policy question is: do these new transfer laws reduce crime? In examining the research evidence, Fagan finds that rates of juvenile offending are not lower in states where it is relatively more common to try adolescents as adults. Likewise, juveniles who have been tried as adults are no less likely to re-offend than their counterparts who have been tried as juveniles. Treating juveniles as adult criminals, Fagan concludes, is not effective as a means of crime control.

Fagan argues that the proliferation of transfer regimes over the past several decades calls into question the very rationale for a juvenile court. Transferring adolescent offenders to the criminal court exposes them to harsh and sometimes toxic forms of punishment that have the perverse effect of increasing criminal activity. The accumulating evidence on transfer, the recent decrease in serious juvenile crime, and new gains in the science of adolescent development, concludes Fagan, may be persuading legislators, policymakers, and practitioners that eighteen may yet again be the appropriate age for juvenile court jurisdiction.

www.futureofchildren.org 


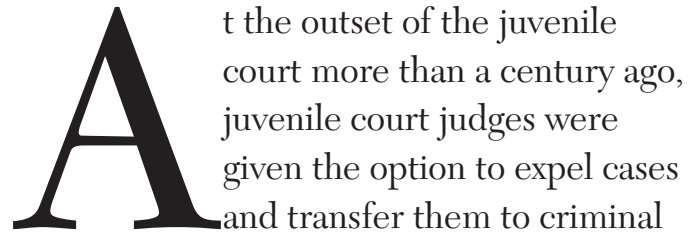

court. Transfer was an essential and necessary feature of the institutional architecture of the new juvenile court. Indeed, transfer helped maintain the court's legitimacy by removing hard cases that challenged the court's comparative advantage in dealing with young offenders - cases that critics could use to launch attacks on the court's efficacy and therefore its core jurisprudential and social policy rationales.

Unlike today, though, hard cases in the early years of the juvenile court did not necessarily involve children charged with murder or other violence. Rather, the youth who were expelled more often were thought to be "incorrigible"-repetitive delinquents whose failure to respond to the court's therapeutic regime signaled the intractability of their developmental and social deficits. ${ }^{1}$ Such cases negated the theory of the court: these youth's repeated failures to respond to treatment canceled their eligibility for protection from the harmful regimes of criminal punishment. In fact, for more than five decades, juveniles charged with murder were more likely than not to be retained in the juvenile court, beneficiaries of both its diversionary and stigma avoidance rationales. $^{2}$

During these years, decisions to transfer youth to criminal court were made routinely and almost exclusively by juvenile court judges with little attention or scrutiny from legislators, advocates, scholars, or the press. Their decisions were individualized to the unique factors for each youth. That is, judges decided which youth were immature and "amenable to treatment" on a case-by-case basis. In some instances, transfer decisions were based on the severity of the offense, where principles of proportionality - the requirement that the punishment fit the crime-trumped collateral considerations that might have otherwise mitigated the case for transfer.

These procedures lasted for decades, until 1966, when the U.S. Supreme Court in Kent v. U.S. identified constitutionally sanctioned standards, criteria, and procedures governing decisions by the juvenile court to waive its jurisdiction over the offending adolescent. ${ }^{3}$ Signs of "maturity" and "sophistication" in the crime were important parts of the Kent calculus, signaling to the judge that the young offender posed a danger for further crimes. Adolescents who were deemed "amenable to treatment" were retained in the juvenile court. In deciding whom to waive to the criminal court and whom to retain in the juvenile court, judges relied heavily on the evaluations of social work professionals whose recommendations on waiver were usually persuasive and authoritative to the court.

Kent was decided during the mid-1960s, when both juvenile and adult crime began to spike in the United States. In reaction to the sharp rise in crime, many states began in the mid-1970s to redesign the laws and revise the philosophy that had long shaped the boundary between juvenile and criminal courts. Popular reactions to rising crime and violence shaped the social and political context of the restructuring, a process that continued through the late 1990s, when juvenile crime began a decade-long decline. As adolescents came increasingly to be feared as perpetrators of the most serious and violent crimes, the principles of rehabilitation that were essential to the juvenile court were largely abandoned. ${ }^{4}$ Judicial discretion was weakened. In some 
states, judicial authority was replaced with politically designed sentencing structures that fixed punishment to crime seriousness. ${ }^{5}$ In other states, the decision whether to try a juvenile as an adult was either shifted to the prosecutor or was made by legislators who carved out large groups of youth who were excluded from the juvenile court.

Demands for dismantling the juvenile court's judicially centered waiver regime focused on four issues: inconsistencies and disparities from one case to the next, racial biases, insensitivity by judges to the seriousness of adolescent crimes, and rising rates of serious juvenile crime that signaled the failure of the juvenile court and corrections to control youth crime. ${ }^{6}$ The critiques motivated state legislatures across the country to remove judicial discretion by disqualifying large sectors of the juvenile court population-children as young as ten years of age - and removing them to the jurisdiction of the criminal court. ${ }^{7}$ The result was a recurring cycle of legislation, starting in 1978 and lasting for more than two decades, that redrew the boundaries between juvenile and adult court. State legislators passed new laws and revised old ones, steadily expanding the criteria for transfer to the criminal court and punishment as an adult. ${ }^{8}$ In effect, the legislatures decided that adolescent offenders had become criminally culpable and more dangerous at younger ages than they were in the past.

This cycle of legislation also reassigned-from juvenile court judges to prosecutors, criminal court judges, legislators, and correctional professionals - a large share of the discretion over the types of cases to be transferred. Today, decisions about court jurisdiction sometimes are made in a retail process repeated daily in juvenile courts or prosecutors' offices; at other times, corrections officials may decide which youth can be released early and which will serve the balance of long prison sentences; and at other times, the choice is made in a wholesale legislative process by elected officials far removed from the everyday workings of the juvenile courts.

These choices involve not just two very different court systems, but deeply held assumptions about the nature of youth crime, about the blameworthiness of youth who commit crimes, and about how society should reconcile the competing concerns of public safety, victim rights, and youth development. The two courts have sharply contrasting ideas about adolescents who break the law-their immaturity and culpability, whether they can be treated or rehabilitated, the security threats they pose, and the punishment they might deserve. Whatever the motivation, sending an adolescent offender to the criminal court is a serious and consequential step. It is an irreversible decision that exposes young lawbreakers to harsh and sometimes toxic forms of punishment that, as the empirical evidence shows, have the perverse effect of increasing criminal activity. ${ }^{9}$

Nearly four decades after Kent and three decades after this restructuring began, it is now possible to look at the results of this large-scale experiment in youth and crimecontrol policy. In this article I examine the new boundaries of the juvenile court from three different perspectives. The first perspective is doctrinal or statutory: what is the legal architecture of the new boundarydrawing and boundary-maintenance regimes? The second perspective is conceptual and jurisprudential: what are the justifications for the adult punishment of juvenile offenders, and what do the new boundaries signal about popular views on youth crime, about the appropriate responses to such crime, and 
about the theory of a juvenile court stripped of its most challenging cases? The third perspective involves policy. Looking at the new boundaries from a policy perspective requires assessing empirical evidence on the reach, consequences, and effectiveness of relocating entire groups of juvenile offenders and offenses to the criminal court. After revisiting the jurisprudential and policy issues that are the heart of this debate, I look to the future of law and policy regulating the upper boundary of the juvenile court.

\section{Statutory Architecture of Juvenile Transfer}

In the midst of the 1978 New York gubernatorial election, a fifteen-year-old named Willie Bosket shot three strangers on a New York City subway platform. ${ }^{10}$ The horrific murder evoked a fierce legislative response. The traditionally shorter sentences in the juvenile court for dangerous young men like Willie became the focus of widespread outrage and, quickly, political action. New York legislators promptly passed the Juvenile Offender Law, ${ }^{11}$ which lowered the age of majority for murder to thirteen and to fourteen for other major felonies. The new law signaled a broad attack on the structure and independence of the juvenile court, a major restructuring of the border between juvenile and criminal court that was repeated across the nation in recurring cycles for more than two decades.

\section{Current Boundary-Drawing Regimes}

At its birth, the Juvenile Offender Law was, and remains today, the nation's toughest law on juvenile crime. New York State was already tough on juvenile crime, one of three states in the nation where the age of majority was sixteen. ${ }^{12}$ Two years earlier, it had passed the Predicate Felony Law, a measure that mandated minimum terms of confinement for serious juvenile offenders in juvenile corrections facilities. ${ }^{13}$ Determinacy in sentencing - that is, introducing certainty both in sentence length and in conditionswas nothing new for adults, but this law was the first of its kind for juveniles. ${ }^{14}$ But the JO Law, as it came to be known, trumped the Predicate Felony Law in ways that signaled the trend that was to come.

First, the legislative branch itself assumed transfer authority by excluding entire categories of juvenile offenders and offenses from the jurisdiction of the family court and removing them to the criminal court. ${ }^{15}$ The lawmakers could simply have curtailed the discretion of family court judges, but the JO Law foreclosed any role for them. One reading of the law, then, was as an attack on the family court and its deep adherence to the principles of individualized justice and "best interests of the child." The JO Law not only stripped transfer authority from family court judges, but also devolved it to police and prosecutors, whose unreviewable decisions about charging young offenders often determined whether cases met the thresholds that would trigger a transfer. ${ }^{16}$

Second, the new law based the transfer decision solely on age and offense. It accorded no weight to culpability, mitigation, or any other individual factor, including either therapeutic needs or prior record. It assumed that all youth in these age-offense categories were both sufficiently culpable as to merit criminal justice sanctions and likely to continue their criminal behavior regardless of any interventions provided for them in juvenile corrections. In effect, the legislators made an actuarial group prediction of future dangerousness.

Third, the new law made sentences for Juvenile Offenders, the label applied to juveniles whose cases were removed by the law, long 
Table 1. Transfer Mechanisms by State, 2003

\begin{tabular}{|c|c|c|c|c|c|c|c|c|c|}
\hline & \multicolumn{3}{|c|}{ Judicial waiver } & \multirow{2}{*}{$\begin{array}{l}\text { Direct } \\
\text { file }\end{array}$} & \multirow{2}{*}{$\begin{array}{l}\text { Statutory } \\
\text { exclusion }\end{array}$} & \multirow{2}{*}{$\begin{array}{l}\text { Reverse } \\
\text { waiver }\end{array}$} & \multirow{2}{*}{$\begin{array}{l}\text { Once adult/ } \\
\text { always adult }\end{array}$} & \multirow{2}{*}{$\begin{array}{l}\text { Juvenile } \\
\text { blended }\end{array}$} & \multirow{2}{*}{$\begin{array}{l}\text { Criminal } \\
\text { blended }\end{array}$} \\
\hline & Discretionary & Presumptive & Mandatory & & & & & & \\
\hline Total states & 45 & 15 & 15 & 15 & 29 & 25 & 34 & 15 & 17 \\
\hline Alabama & $\mathrm{X}$ & & & & $\mathrm{X}$ & & $\mathrm{X}$ & & \\
\hline Alaska & $x$ & $\mathrm{x}$ & & & $x$ & & & $\mathrm{x}$ & \\
\hline Arizona & $x$ & & & $x$ & $x$ & $x$ & $x$ & & \\
\hline Arkansas & $x$ & & & $x$ & & $x$ & & $x$ & $x$ \\
\hline California & $x$ & $x$ & & $x$ & $x$ & $x$ & $x$ & & $x$ \\
\hline Colorado & $x$ & $\mathrm{x}$ & & $x$ & & $x$ & & $\mathrm{x}$ & $x$ \\
\hline Connecticut & & & $\mathrm{x}$ & & & $x$ & & $\mathrm{x}$ & \\
\hline Delaware & $x$ & & $x$ & & $x$ & $x$ & $x$ & & \\
\hline District of Columbia & $x$ & $\mathrm{X}$ & & $x$ & & & $\mathrm{x}$ & & \\
\hline Florida & $x$ & & & $x$ & $\mathrm{x}$ & & $x$ & & $\mathrm{x}$ \\
\hline Georgia & $x$ & & $x$ & $x$ & $x$ & $\mathrm{X}$ & & & \\
\hline Hawaii & $\mathrm{x}$ & & & & & & $x$ & & \\
\hline Idaho & $x$ & & & & $\mathrm{x}$ & & $\mathrm{x}$ & & $x$ \\
\hline Illinois & $x$ & $x$ & $x$ & & $x$ & $\mathrm{x}$ & $x$ & $x$ & $x$ \\
\hline Indiana & $x$ & & $x$ & & $x$ & & $x$ & & \\
\hline lowa & $\mathrm{x}$ & & & & $\mathrm{x}$ & $\mathrm{x}$ & $x$ & & $x$ \\
\hline Kansas & $x$ & $x$ & & & & & $\mathrm{x}$ & $x$ & \\
\hline Kentucky & $x$ & & $x$ & & & $x$ & & & $x$ \\
\hline Louisiana & $x$ & & $x$ & $\mathrm{x}$ & $\mathrm{x}$ & & & & \\
\hline Maine & $x$ & $\mathrm{X}$ & & & & & $\mathrm{X}$ & & \\
\hline Maryland & $x$ & & & & $\mathrm{x}$ & $\mathrm{x}$ & $x$ & & \\
\hline Massachusetts & & & & & $\mathrm{x}$ & & & $\mathrm{X}$ & $\mathrm{x}$ \\
\hline Michigan & $\mathrm{x}$ & & & $\mathrm{x}$ & & & $\mathrm{x}$ & $x$ & $x$ \\
\hline Minnesota & $x$ & $\mathrm{x}$ & & & $\mathrm{x}$ & & $x$ & $x$ & \\
\hline Mississippi & $x$ & & & & $x$ & $\mathrm{x}$ & $x$ & & \\
\hline Missouri & $x$ & & & & & & $x$ & & $\mathrm{x}$ \\
\hline Montana & & & & $\mathrm{x}$ & $\mathrm{x}$ & $\mathrm{x}$ & & $\mathrm{x}$ & \\
\hline Nebraska & & & & $x$ & & $x$ & & & $x$ \\
\hline Nevada & $\mathrm{x}$ & $\mathrm{x}$ & & & $\mathrm{x}$ & $x$ & $x$ & & \\
\hline New Hampshire & $x$ & $x$ & & & & & $x$ & & \\
\hline New Jersey & $x$ & $x$ & $\mathrm{x}$ & & & & & & \\
\hline New Mexico & & & & & $\mathrm{x}$ & & & $\mathrm{x}$ & $x$ \\
\hline New York & & & & & $x$ & $\mathrm{x}$ & & & \\
\hline North Carolina & $x$ & & $x$ & & & & $x$ & & \\
\hline North Dakota & $x$ & $x$ & $x$ & & & & $x$ & & \\
\hline Ohio & $x$ & & $x$ & & & & $x$ & $\mathrm{x}$ & \\
\hline Oklahoma & $x$ & & & $x$ & $x$ & $x$ & $x$ & & $x$ \\
\hline Oregon & $x$ & & & & $x$ & $\mathrm{X}$ & $x$ & & \\
\hline Pennsylvania & $\mathrm{x}$ & $x$ & & & $\mathrm{x}$ & $\mathrm{X}$ & $x$ & & \\
\hline Rhode Island & $x$ & $x$ & $x$ & & & & $x$ & $x$ & \\
\hline South Carolina & $x$ & & $x$ & & $x$ & & & & \\
\hline South Dakota & $x$ & & & & $x$ & $\mathrm{x}$ & $x$ & & \\
\hline Tennessee & $x$ & & & & & $x$ & $x$ & & \\
\hline Texas & $x$ & & & & & & $x$ & $x$ & \\
\hline Utah & $x$ & $x$ & & & $x$ & & $x$ & & \\
\hline Vermont & $x$ & & & $x$ & $x$ & $x$ & & $x$ & \\
\hline Virginia & $x$ & & $\mathrm{X}$ & $x$ & & $x$ & $\mathrm{X}$ & & $x$ \\
\hline Washington & $x$ & & & & $x$ & & $x$ & & \\
\hline West Virginia & $x$ & & $x$ & & & & & & $x$ \\
\hline Wisconsin & $x$ & & & & $\mathrm{x}$ & $x$ & $\mathrm{X}$ & & $x$ \\
\hline Wyoming & $x$ & & & $x$ & & $\mathrm{X}$ & & & \\
\hline
\end{tabular}

Source: Patrick Griffin, Trying and Sentencing Juveniles as Adults: An Analysis of State Transfer and Blended Sentencing Laws (Pittsburgh: National Center for Juvenile Justice, 2003). 
enough to require trans-correctional placements_placements that began in juvenile settings and continued into the adult corrections system. Thus the law not only mandated transfers but made them routine, a move that affected large numbers of younger offenders who were sentenced to lengthy prison terms despite the absence of a prior record.

In the next two decades, every state in the nation passed legislation to ease and expand the prosecution of juveniles in adult courts. ${ }^{17}$ The watershed year was 1995, when seventeen states expanded eligibility for transfer. ${ }^{18}$ Most states supplanted or eclipsed the traditional system of judicial transfer from the juvenile court using one or more of the mechanisms built into the design of the JO Law. Still other laws created a new statutory authority to transfer not court jurisdiction but correctional jurisdiction, and ceded that authority to a forum that is more administrative than adjudicative. ${ }^{19}$ Some states maintained the structure and primacy of judicial waiver, but increased the number of youth being waived by mandating that waiver be considered for some offense and offender categories and shifting the burden of proof from the prosecution to the defense to show why the accused should not be transferred to the criminal court.

Given its scope and reach, the expansion of transfer for juvenile offenders was a massive social and legal experiment that fundamentally transformed the borders and boundaries of the juvenile justice system. The experiment evolved and strengthened over time: once passed, laws often were re-crafted in recurring legislative sessions to further expand the scope of laws to transfer or remove youth to criminal court at lower ages and for more offenses. As I show below, the experiment took on several unique forms.

\section{Mechanisms for Juvenile Transfer}

Table 1 arrays the states on each of the mechanisms of juvenile transfer in effect as of 2004. Judicial waiver, statutory exclusion, direct file, and blended sentencing are the mechanisms used to transfer juvenile offenders to adult court.

Judicial waiver. Judicial waiver to criminal court is the most common transfer mechanism: forty-seven states and the District of Columbia provide judicial discretion to waive certain juveniles to criminal court. Table 2 shows the age and offense thresholds of waiver eligibility for each state. Historically, judicial waiver decisions were made following a motion by prosecutors. Evidence was presented and argued, and a decision was made. In 1966, in Kent v. U.S., ${ }^{20}$ the Supreme Court articulated both procedural and substantive standards to regulate judicial waiver decisions. Though only advisory in the original Kent case, the Kent guidelines quickly were adopted into law in most states.

Since 1978, judicial waiver criteria and procedures have been redesigned in many states to increase the likelihood of waiver. Some states created a presumption of waiver for specific offenses or offenders, based on age, offense, or prior record. Presumptive waiver shifts the burden of proof from the state to the juvenile to show that he or she should not be transferred. Other states mandate waiver for specific categories of offenses and offenders, often to ensure sentencing terms that can take place only in the criminal court.

Statutory exclusion. Statutory exclusions, like New York's JO Law, relocate entire categories of youth defined by age or offense criteria, or both, to the criminal court. More than half of the states have statutes that exclude some adolescent offenders from the juvenile court. 
Table 2. Eligibility for Judicial Waiver by State, Age, and Offense Type, 2003

\begin{tabular}{|c|c|c|c|c|c|c|c|c|}
\hline State & $\begin{array}{c}\text { Any } \\
\text { offense }\end{array}$ & $\begin{array}{l}\text { Certain } \\
\text { felonies }\end{array}$ & $\begin{array}{l}\text { Capital } \\
\text { crime }\end{array}$ & Murder & $\begin{array}{l}\text { Person } \\
\text { offense }\end{array}$ & $\begin{array}{l}\text { Property } \\
\text { offense }\end{array}$ & $\begin{array}{c}\text { Drug } \\
\text { offense }\end{array}$ & $\begin{array}{c}\text { Weapons } \\
\text { offense }\end{array}$ \\
\hline Alabama & 14 & & & & & & & \\
\hline Alaska & NS & & & & & & & \\
\hline Arizona & & NS & & & & & & \\
\hline Arkansas & & 14 & 14 & 14 & 14 & & & 14 \\
\hline California & 16 & & & & & & & \\
\hline Colorado & & 12 & & 12 & 12 & & & \\
\hline Delaware & NS & & & & & & & \\
\hline District of Columbia & 16 & 15 & & & & & & NS \\
\hline Florida & 14 & & & & & & & \\
\hline Georgia & 15 & & 13 & & 13 & & & \\
\hline Hawaii & & 14 & & NS & & & & \\
\hline Idaho & 14 & NS & & NS & NS & NS & NS & \\
\hline Illinois & 13 & & & & & & & \\
\hline Indiana & 14 & 16 & & 10 & & & 16 & \\
\hline lowa & 14 & & & & & & & \\
\hline Kansas & 10 & & & & & & & \\
\hline Kentucky & & 14 & 14 & & & & & \\
\hline Louisiana & & & & 14 & 14 & & & \\
\hline Maine & & NS & & & & & & \\
\hline Maryland & 15 & & NS & & & & & \\
\hline Michigan & & 14 & & & & & & \\
\hline Minnesota & & 14 & & & & & & \\
\hline Mississippi & 13 & & & & & & & \\
\hline Missouri & & 12 & & & & & & \\
\hline Nevada & & 14 & & & & & & \\
\hline New Hampshire & & 15 & & 13 & 13 & & & \\
\hline New Jersey & 14 & & & 14 & 14 & 14 & 14 & 14 \\
\hline North Carolina & & 13 & & & & & & \\
\hline North Dakota & 16 & & & & 14 & & & \\
\hline Ohio & & 14 & & & & & & \\
\hline Oklahoma & & NS & & & & & & \\
\hline Oregon & & 15 & & NS & NS & 15 & & \\
\hline Pennsylvania & & 14 & & & & & & \\
\hline Rhode Island & & 16 & NS & & & & & \\
\hline South Carolina & 16 & 14 & & NS & NS & & 14 & 14 \\
\hline South Dakota & & NS & & & & & & \\
\hline Tennessee & 16 & & & NS & NS & & & \\
\hline Texas & & 14 & 14 & & & & 14 & \\
\hline Utah & & 14 & & & & & & \\
\hline Vermont & & & & 10 & 10 & 10 & & \\
\hline Virginia & & 14 & & & & & & \\
\hline Washington & NS & & & & & & & \\
\hline West Virginia & & NS & & NS & NS & NS & NS & \\
\hline Wisconsin & 15 & 14 & & 14 & 14 & 14 & 14 & \\
\hline Wyoming & 13 & & & & & & & \\
\hline
\end{tabular}

Note: An entry in the column below an offense category means that there is some offense or offenses in that category for which a juvenile may be waived for criminal prosecution. The number indicates the youngest possible age at which a juvenile accused of an offense in that category may be waived. "NS" means no age restriction is specified for an offense in that category.

Example: In Tennessee, a juvenile may be waived for criminal prosecution of any offense committed after reaching the age of sixteen (Any offense-16). In addition, a juvenile of any age may be waived for prosecution of first- or second-degree murder or attempted first- or second-degree murder (Murder-NS). Finally, a juvenile of any age may be waived for prosecution of rape, aggravated rape, aggravated or especially aggravated robbery, kidnapping, aggravated or especially aggravated kidnapping, or the attempt to commit any of these offenses (Person offense-NS).

Source: Patrick Griffin, Trying and Sentencing Juveniles as Adults: An Analysis of State Transfer and Blended Sentencing Laws (Pittsburgh: National Center for Juvenile Justice, 2003). 
Table 3. State Array of Statutory Exclusions of Minors from Juvenile Court by Age and Offense Type, 2003

\begin{tabular}{|c|c|c|c|c|c|c|c|c|}
\hline State & Any offense & $\begin{array}{l}\text { Certain } \\
\text { felonies }\end{array}$ & $\begin{array}{l}\text { Capital } \\
\text { crimes }\end{array}$ & Murder & $\begin{array}{l}\text { Person } \\
\text { offense }\end{array}$ & $\begin{array}{c}\text { Property } \\
\text { offense }\end{array}$ & Drug offense & $\begin{array}{c}\text { Weapons } \\
\text { offense }\end{array}$ \\
\hline Alabama & & 16 & 16 & & & & 16 & \\
\hline Alaska & & & & & 15 & 16 & & \\
\hline Arizona & & 15 & & 15 & 15 & & & \\
\hline California & & & & 14 & 14 & & & \\
\hline Delaware & & 15 & & & & & & \\
\hline Florida & & & & 16 & NS & 16 & 16 & \\
\hline Georgia & & & & 13 & 13 & & & \\
\hline Idaho & & & & 14 & 14 & 14 & 14 & \\
\hline Illinois & & 15 & & 13 & 15 & & 15 & 15 \\
\hline Indiana & & 16 & & 16 & 16 & & 16 & 16 \\
\hline lowa & & 16 & & & & & 16 & 16 \\
\hline Louisiana & & & & 15 & 15 & & & \\
\hline Maryland & & & 14 & 16 & 16 & & & 16 \\
\hline Massachusetts & & & & 14 & & & & \\
\hline Minnesota & & & & 16 & & & & \\
\hline Mississippi & & 13 & 13 & & & & & \\
\hline Montana & & & & 17 & 17 & 17 & 17 & 17 \\
\hline Nevada & $16 *$ & NS & & NS & 16 & & & \\
\hline New Mexico & & & & 15 & & & & \\
\hline New York & & & & 13 & 14 & 14 & & 14 \\
\hline Oklahoma & & & & 13 & & & & \\
\hline Oregon & & & & 15 & 15 & & & \\
\hline Pennsylvania & & & & NS & 15 & & & \\
\hline South Carolina & & 16 & & & & & & \\
\hline South Dakota & & 16 & & & & & & \\
\hline Utah & & 16 & & 16 & & & & \\
\hline Vermont & & & & 14 & 14 & 14 & & \\
\hline Washington & & & & 16 & 16 & 16 & & \\
\hline Wisconsin & & & & 10 & NS & & & \\
\hline
\end{tabular}

Note: An entry in the column below an offense category means that there is some offense or offenses in that category that are excluded from juvenile court jurisdiction. The number indicates the youngest possible age at which a juvenile accused of an offense in that category is subject to the exclusion. "NS" means no age restriction is specified for an offense in that category.

Source: Patrick Griffin, Trying and Sentencing Juveniles as Adults: An Analysis of State Transfer and Blended Sentencing Laws (Pittsburgh: National Center for Juvenile Justice, 2003).

* In Nevada, the exclusion applies to any juvenile with a previous felony adjudication, regardless of the current offense charged, if the current offense involves the use or threatened use of a firearm.

Table 3 shows the age and offense threshold for statutory exclusion in each of those states. In addition to devolving transfer authority to prosecutors and police, these statutes also moot Kent by rendering a legislative judgment about the future behavior and malleability of excluded youth. Exclusions vary from specific offenses, as in New York, to any felony offense at the age of seventeen, as in Mississippi.

Concurrent jurisdiction and direct file.

Concurrent jurisdiction gives prosecutors the option and discretion to file cases directly in adult court. Fifteen states have created concurrent juvenile and criminal court jurisdiction for specific categories of offenses and offenders, permitting prosecutors to elect the judicial forum for the adjudication and sentencing of the young offender. Table 4 shows the combinations of offense and age criteria that trigger eligibility for concurrent jurisdiction in each state. A quick glance shows that these statutes are targeted primarily at violent crimes. Most states with 
Table 4. State Array of Concurrent Jurisdiction Statutes Permitting Direct File by Prosecutor by Age and Offense, 2003

\begin{tabular}{|c|c|c|c|c|c|c|c|c|}
\hline State & $\begin{array}{c}\text { Any } \\
\text { offense }\end{array}$ & $\begin{array}{l}\text { Certain } \\
\text { felonies }\end{array}$ & $\begin{array}{l}\text { Capital } \\
\text { crime }\end{array}$ & Murder & $\begin{array}{l}\text { Person } \\
\text { offense }\end{array}$ & $\begin{array}{c}\text { Property } \\
\text { offense }\end{array}$ & $\begin{array}{c}\text { Drug } \\
\text { offense }\end{array}$ & $\begin{array}{c}\text { Weapons } \\
\text { offense }\end{array}$ \\
\hline Arizona & & 14 & & & & & & \\
\hline Arkansas & & 16 & 14 & 14 & 14 & & & \\
\hline California & & 14 & 14 & 14 & 14 & 14 & 14 & \\
\hline Colorado & & 14 & & 14 & 14 & 14 & & 14 \\
\hline District of Columbia & & & & 16 & 16 & 16 & & \\
\hline Florida & 16 & 16 & NS & 14 & 14 & 14 & & 14 \\
\hline Georgia & & & NS & & & & & \\
\hline Louisiana & & & & 15 & 15 & 15 & 15 & \\
\hline Michigan & & 14 & & 14 & 14 & 14 & 14 & \\
\hline Montana & & & & 12 & 12 & 16 & 16 & 16 \\
\hline Nebraska & 16 & NS & & & & & & \\
\hline Oklahoma & & 16 & & 15 & 15 & 15 & 16 & 15 \\
\hline Vermont & 16 & 1 & & & & & & \\
\hline Virginia & & & & 14 & 14 & & & \\
\hline Wyoming & & 14 & & 14 & 14 & 14 & & \\
\hline
\end{tabular}

Note: An entry in the column below an offense category means that there is some offense or offenses in that category that may be handled in juvenile or criminal court at the prosecutor's option. The number indicates the youngest possible age at which a juvenile accused of an offense in that category is subject to criminal prosecution at the prosecutor's option. "NS" means no age restriction is specified for an offense in that category.

Example: Wyoming provides for concurrent jurisdiction of the following offenses committed by fourteen-year-olds: any felony committed by a juvenile with at least two previous felony adjudications (Certain felonies-14); murder or manslaughter (Murder-14); kidnapping, first- or second-degree sexual assault, robbery, aggravated assault, or aircraft high-jacking (Person offense-14); first- or seconddegree arson and aggravated burglary (Property offense-14).

Source: Patrick Griffin, Trying and Sentencing Juveniles as Adults: An Analysis of State Transfer and Blended Sentencing Laws (Pittsburgh: National Center for Juvenile Justice, 2003).

concurrent jurisdiction make youth eligible at age fourteen, though others have either lower or higher age thresholds for specific crimes.

Blended sentencing. Seventeen states give the criminal court the power to impose contingent criminal sanctions for juveniles convicted of certain serious crimes; fifteen states permit juvenile courts to do the same; many give the power to either court. These statutes, known as blended sentencing statutes or extended jurisdiction statutes, identify a specific group of juveniles_-based on age, offense, and prior record-whose sentences have separate juvenile and adult components that are linked through a contingent process to determine whether the extended (criminal) punishment will be carried out. ${ }^{21}$ Typically, the adult component is imposed only if the youth violates the provisions of the juvenile portion or commits a new offense. The conditions in the juvenile phase may be narrowly tailored (for example, avoiding subsequent crime) or vague and subjective (for example, making satisfactory "progress" in treatment). Table 5 shows the offense and age criteria for blended sentencing in the states with such provisions. Two states, Vermont and Kansas, permit blended sentences for any offense for youth beginning at age ten. Many other states have no minimum age for one or more of the eligible offense categories.

Although intended to ameliorate the consequences of transfer and waiver, blended sentencing in practice has raised several issues. First is net widening. In Minnesota, for example, blended sentences did not 
Table 5. State Array of Blended Sentencing Statutes by Age and Offense Type, 2003

\begin{tabular}{|c|c|c|c|c|c|c|c|c|c|}
\hline State & $\begin{array}{c}\text { Statute } \\
\text { type* }\end{array}$ & $\begin{array}{c}\text { Any } \\
\text { offense }\end{array}$ & $\begin{array}{r}\text { Certain } \\
\text { felonies } \\
\end{array}$ & $\begin{array}{c}\text { Capital } \\
\text { crime }\end{array}$ & Murder & $\begin{array}{l}\text { Person } \\
\text { offense }\end{array}$ & $\begin{array}{c}\text { Property } \\
\text { offense }\end{array}$ & $\begin{array}{c}\text { Drug } \\
\text { offense }\end{array}$ & $\begin{array}{c}\text { Weapons } \\
\text { offense }\end{array}$ \\
\hline Alaska & 1 & & & & & 16 & & & \\
\hline Arkansas & 1 & & 14 & & NS & 14 & & & 14 \\
\hline Colorado & $\mathrm{C}$ & & NS & & & NS & & & \\
\hline Connecticut & 1 & & 14 & & & NS & & & \\
\hline Illinois & 1 & & 13 & & & & & & \\
\hline Kansas & 1 & 10 & & & & & & & \\
\hline Massachusetts & 1 & & 14 & & & 14 & & & 14 \\
\hline Michigan & 1 & NS & NS & & NS & NS & NS & NS & \\
\hline Minnesota & 1 & & 14 & & & & & & \\
\hline Montana & 1 & & 12 & & NS & NS & NS & NS & NS \\
\hline New Mexico & $E$ & & 14 & & 14 & 14 & 14 & & \\
\hline Ohio & 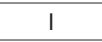 & & 10 & & 10 & & & & \\
\hline Rhode Island & $\mathrm{C}$ & & NS & & & & & & \\
\hline Texas & C & & NS & & NS & NS & & NS & \\
\hline
\end{tabular}

Note: An entry in the column below an offense category means that there is some offense or offenses in that category for which a juvenile may receive a blended sentence in juvenile court. The number indicates the youngest possible age at which a juvenile committing an offense in that category is subject to blended sentencing. "NS" means no age restriction is specified for an offense in that category.

*Statute types are coded "I" for inclusive, "E" for exclusive, and "C" for contiguous.

†Vermont has an anomalous juvenile blended sentencing provision, which permits a juvenile entering a plea of guilty or nolo contendere in a criminal proceeding to petition for transfer to family court for disposition. Following the transfer, the family court must impose both a juvenile disposition and a suspended criminal sentence. However, there is no minimum age/offense threshold for juvenile blended sentencing in such a case- the provision applies to all juveniles transferred from criminal court for Youthful Offender Disposition.

Source: Patrick Griffin, Trying and Sentencing Juveniles as Adults: An Analysis of State Transfer and Blended Sentencing Laws (Pittsburgh: National Center for Juvenile Justice, 2003).

reduce the number of waivers; instead, they were given to youth who in the past were sentenced within the juvenile system. ${ }^{22}$ Second, the decision to activate the adult portion of the transitional sentence often lacks procedural safeguards and at times lacks accountability. States vary on whether the decision is judicial or administrative, as well as on the evidence necessary to trigger the adult portion of the sentence, on the standard of proof, on whether youth can contest or rebut the evidence against them, on whether they are entitled to representation, and on whether the decision is reviewable. Given the length and conditions of the adult portion of the sentence, a more formal, standardized, and constitutionally sound procedure would be appropriate and consistent with the principles of Gault and McKiever.

\section{Competing Instincts and Second Thoughts}

The complexity of state laws, the piecemeal character of the statutory landscape, and the fact that most states have overlapping transfer mechanisms suggests some ambivalence about the instincts to get tough by imposing criminal sanctions on adolescents. Certainly, a state that really wanted to crack down on juveniles could simply lower its age of majority. Yet throughout this thirty-year interval of increasingly tougher sanctions for adolescent offenders, only two states-Wisconsin and New Hampshire- - have done so, lowering the age of majority from seventeen to sixteen. ${ }^{23}$ Between 1989 and 1995, five states abolished the juvenile death penalty, far more than the number of states that lowered the age of majority in the same period. ${ }^{24}$ And one 
state-Connecticut-recently raised its age of majority from sixteen to eighteen.

Instead, the states have criminalized delinquency incrementally and in pieces, stopping short of the more obvious and expedient step of lowering the age of majority. The current statutory landscape is full of trapdoors and loopholes that allow some youth-no one knows exactly how many-to escape the reach of the criminal law and its harsher punishments. Legislators appear ambivalent, refusing to completely abandon the principles of juvenile justice, yet seeking to divide delinquents into two categories: those worthy of the remedial and therapeutic interventions of the juvenile court and those who can be abandoned to the punitive regime of criminal justice in the name of retribution and public safety.

Two collateral provisions of the new transfer mechanisms illustrate these competing instincts about adolescence, youth crime, and juvenile justice. Viewed together, they suggest an ambivalent political and social culture on how tough to get with adolescent criminals. The first provision is reverse waiver, the return of transferred cases back to the juvenile court. Reverse waiver is a retail corrective mechanism, designed to detect errors in attributing full culpability or overlooking evidence of amenability to treatment. Twenty-four states permit reverse waiver once cases have been initiated in the criminal courts, including twenty-one of the states with direct file (or prosecutorial waiver) statutes. ${ }^{25}$ In some states with statutory exclusion, such as Pennsylvania, these decertification hearings are routine. ${ }^{26}$ In New York City, nearly one-third of youth excluded by statute from family court are returned there by the adult court. ${ }^{27}$ Cases can be returned to the juvenile court either for adjudication and sentencing or only for sentencing within its statutory authority.

The opposite instinct is evident in the thirtyone states that have enacted "once waived, always waived" legislation. In these states, juveniles who have been waived to adult court and convicted subsequently must be charged in criminal court regardless of the offense. For example, in Virginia, any juvenile previously convicted as an adult is forever excluded from juvenile court jurisdiction. In California, any youth whose case is waived to criminal court qualifies for permanent waiver, regardless of whether he or she is convicted in the first waived case. Permanent waiver can be invoked in ten states, and must be invoked in twelve others, if the offender previously has been adjudicated delinquent.

Thus, the punitive and child-saver instincts for youth crime co-exist uneasily in the current statutory environment, forcing a binary choice between criminal and juvenile court jurisdiction, a choice that is not well suited to reconcile these tensions.

\section{The Enduring Importance of Maturity and Development in Juvenile Justice} What, then, do twenty-five years of transfer activism signal about legal and popular notions of the culpability and maturity of adolescents and about the place of developmental considerations in juvenile justice? The political discourse and legal mobilization that animated the criminalization push beginning in the 1970s was ambiguous about maturity. From the outside, legal academics read the movement as a sign that legislators assumed that young offenders have reached a developmental threshold of criminal responsibility that makes them fully culpable for their crimes. ${ }^{28}$ Indeed, even the Kent regulations confused "sophistication of the crime" with 
"maturity" and culpability. Critics of the juvenile court argued that proportionality and the concerns of victims should trump the "best interests of the child." Some argued that proportionality was necessary to maintain the legitimacy of the juvenile court. ${ }^{29}$ Others recommended a proportionality regime in the interests of fairness and consistency, deemphasizing but not discarding the notions of immaturity and diminished culpability of adolescents. ${ }^{30}$ Public safety concerns also loomed large, with proponents wishing to draw hard lines to determine when longer, incapacitating punishments were needed to protect citizens. Still other critics of the juvenile court preferred the deterrent effects of criminal court punishment over a regime of individualized justice. The notion of immaturity as a culpability discount was set aside or standardized in a complex heuristic of when and for whom transfer is necessary.

Accordingly, the transfer activism of the past two decades did not affirmatively or uniformly reject the notion of developmental immaturity and diminished culpability of youth. In many instances, it merely reserved it for less serious or visible offenders.

Functionally, though not explicitly, transfer activism assumes that adolescents are no different from adults in the capacities that comprise maturity and hence culpability. It also assumes that adolescents have the same competencies as adults to understand and meaningfully participate in criminal proceedings. In the absence of good social and behavioral science, legislators were free to make those assumptions.

But as Elizabeth Scott and Laurence Steinberg show in their article in this volume, there are good reasons now to doubt these claims. ${ }^{31}$ For example, in Roper v. Simmons, ${ }^{32}$ the 2005 U.S. Supreme Court decision banning execution of adolescents younger than eighteen who commit capital murder, the Court took notice that juveniles are less culpable because they are "more vulnerable and susceptible to negative peer influences and outside pressures, including peer pressure," 33 and are "comparatively immature, reckless and irresponsible." ${ }^{34}$ The sum of these developmental gaps between adolescents and adults, according to the Roper majority, “. . . means it is less supportable to conclude that even a heinous crime committed by a juvenile is evidence of irretrievably depraved character." 35

\section{While the law moves toward}

waiving increasingly younger teens into criminal court, social and biological evidence

\section{suggests moving in the other direction.}

The Roper court drew both from social science research and from "anatomicallybased" evidence of "concrete differences" between juveniles and adults showing that "critical developmental changes in key brain regions occur only after late adolescence." ${ }^{36}$ So behavioral science and natural science are nearly perfectly aligned to show that "the average adolescent cannot be expected to act with the same control or foresight as a mature adult." 37

The new science of juvenile culpability runs counter to the patterns in transfer law. In transfer law, the downward ratcheting of the age at which youth are exposed to adult punishment is sharply at odds with evidence 
that full maturity in culpability and blameworthiness comes later than eighteen, not earlier. The recent push to lower the age threshold for treating juvenile offenders as adults assumes that they are sufficiently mature to be held culpable for their crimes, that any deficits in their maturity are minor compared with the harm they have done, and that unless punished harshly, they are likely to offend again. The new scientific evidence on developmentally constrained choices suggests that the law has been moving in the wrong direction..$^{38}$

The new developmental and neuropsychological research has strong implications for laws that funnel adolescents wholesale into the adult courts. The new evidence casts reasonable doubt on statutes that sweep all fourteen-, fifteen-, or sixteen-year-old offenders into the criminal justice system. Some adolescent offenders may have reached a threshold of maturity by age sixteen consistent with the legal conceptions of maturity-culpability, but many others have not. In legal regimes that assume maturity where it simply does not exist, the new evidence on immaturity, both in the capacities that comprise culpability and the brain functions that launch them, argues persuasively against transfer to the criminal court.

The alternative to wholesale transfer is to rely on case-by-case assessments, much as the early juvenile courts did in deciding which youth were so incorrigible as to warrant expulsion from the juvenile court. Yet given the limitations of prediction, one might worry about the accuracy of such assessments. ${ }^{39}$ Developmental variability means that the younger the line for eligibility for criminal punishment is drawn, the greater the risk of error. ${ }^{40}$ So, for example, the new science should raise strong cautions about laws that draw the line at age twelve or younger. One can hardly expect legislators, prosecutors, and judges to systematically and accurately make these complex judgments for young adolescents. ${ }^{41}$ Getting it wrong has serious costs. Waiver to adult court is not exactly a death sentence, but it often is irreversible and has serious consequences, as I show next, both for adolescents and for public safety. While the law moves toward waiving increasingly younger teens into criminal court, social and biological evidence suggests moving in the other direction.

\section{The Reach of Transfer Law}

The complexity of the statutory landscape challenges efforts to compile accurate and comprehensive estimates of the reach of transfer laws. ${ }^{42}$ Accurate tallies of the number of adolescents transferred to criminal court would require counts in state court administrative databases of the number of cases filed in the criminal court by age, race, and offense, plus data on their dispositions to determine how many transferred cases remain in criminal court after reverse waiver or judicial review. These data may exist, but they are highly disaggregated by state and, in some instances, exist only in local court records.

\section{How Many Are Transferred?}

Estimates of the number of youth tried and sentenced in the criminal courts are highly sensitive to data sources and methods of counting. Donna Bishop estimates that between 210,000 and 260,000 minors were prosecuted in criminal courts in $1996 .{ }^{43}$ Most of those ( 80 percent) were excluded from juvenile courts either by the statutory age boundary for juvenile court or by statutes that exclude specific categories of offenses and offenders. The Campaign for Youth Justice makes a similar estimate: 7,500 cases are 
Figure 1. Percent of Cases Judicially Waived to Adult Court, 1990-99

Percent

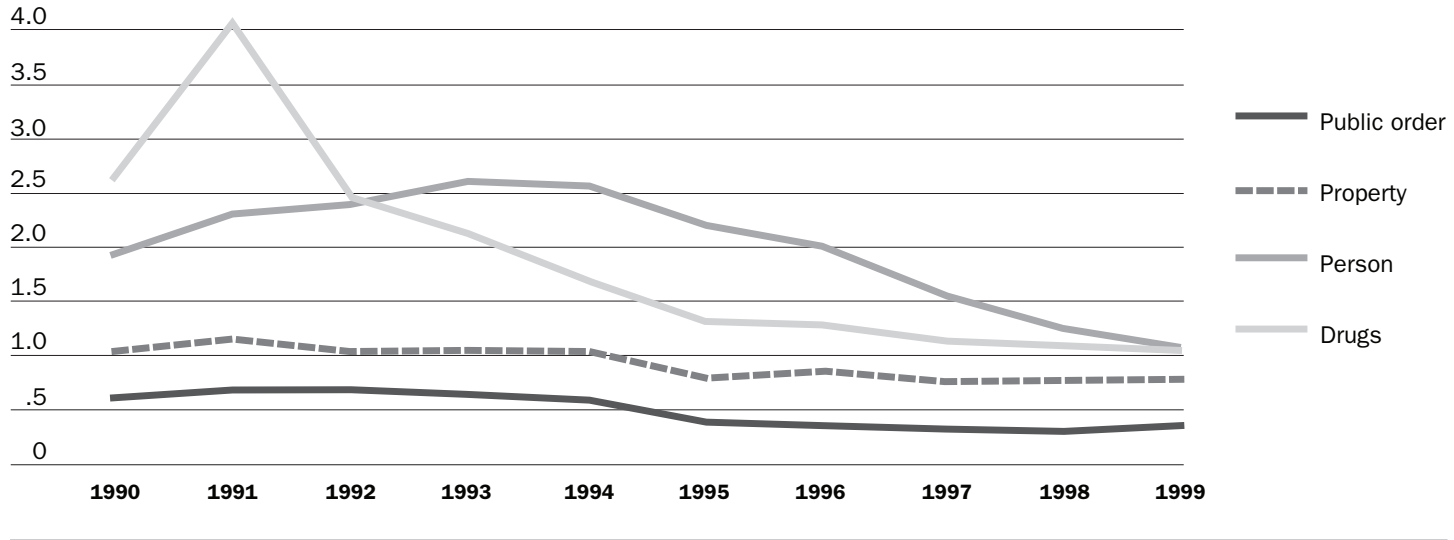

Source: National Center for Juvenile Justice, Delinquency Cases Waived to Adult Court, 1990-99.

judicially waived to criminal court each year, 27,000 are sent by direct file by a prosecutor, and 218,000 completely bypass the juvenile system and are sent by legislation that sets a lower age of adulthood than eighteen. ${ }^{44}$ Comparing this figure with the estimated 973,000 youth who received dispositions in the juvenile court in the same year, Bishop concludes that between 20 and 25 percent of all juvenile offenders younger than eighteen were processed in the criminal courts.

These figures are difficult to verify, however. For example, there are no comprehensive records of direct file activity by prosecutors. And records of minors prosecuted in criminal court are available only for samples from the nation's largest counties and only for some years, ${ }^{45}$ or from surveys of prosecutors who report secondary data of uncertain reliability. These data sources are useful as lead indicators of trends over time, but are not helpful in generating estimates of the number and rate of juvenile offenders in the criminal courts.

Although precise estimates may be elusive, it is possible to verify current estimates by aggregating other evidence. "Front-end statistics" on the number of youth judicially transferred suggest that traffic from juvenile to criminal court is heavy. For example, the National Center for Juvenile Justice examined judicial waiver between 1988 and 1999 in more than 2,000 juvenile courts representing 70 percent of the U.S. population. Figure 1 shows that the rate of waiver is low and, with two exceptions, stable over time.

Approximately eight cases were waived for every 1,000 formally processed over the decade, fewer than 1 percent of all cases. Waiver rates peaked in 1992 at 1.6 percent of all cases and declined through the rest of the decade consistent with an overall decline in juvenile arrests. Person offenses were waived most often during the decade (1.1 percent of all formal cases), and property cases least often. ${ }^{46}$ Judicial waivers for drug offenses declined from a peak of 4 percent in 1991 to slightly more than 1 percent in 1999. Given the low frequency of judicial waivers, the attack on the autonomy of juvenile court judges to make waiver decisions is puzzling.

These front-end statistics on waiver do not include juvenile transfers to criminal court via direct file or statutory exclusions, nor those 
Figure 2. Number of State Jail Inmates under Age Eighteen, 1990-2004

Number of inmates

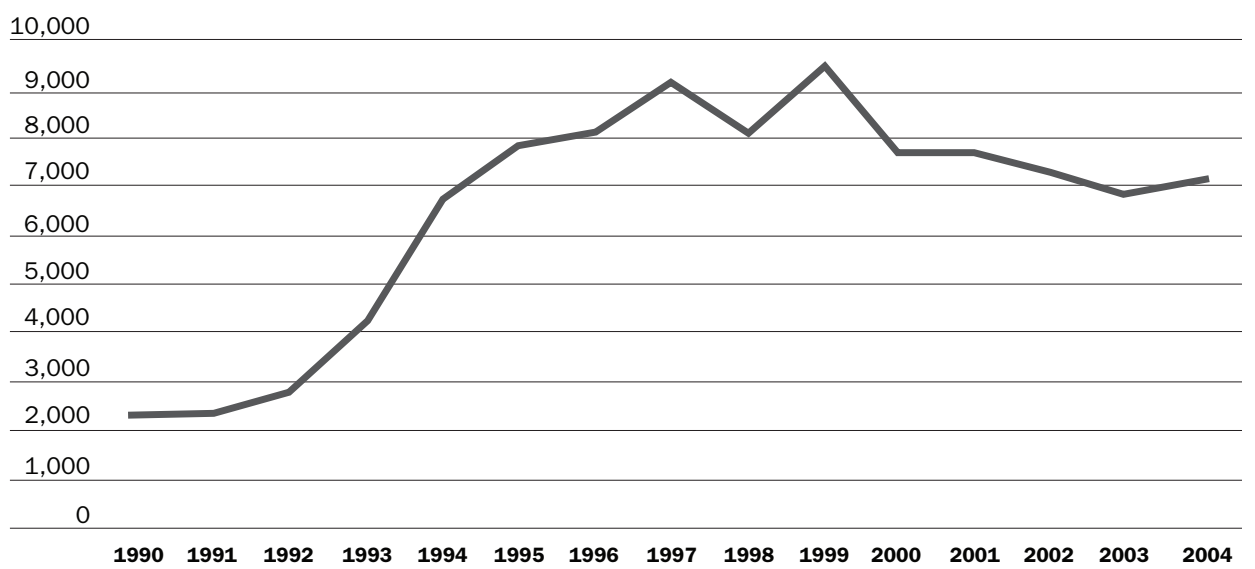

Source: H. Snyder and M. Sickmund, National Center for Juvenile Justice, Juvenile Offenders and Victims: 1999 National Report (www. ncjrs.gov/html/ojjdp/nationalreport99/toc.html [September, 1999]).

minors (as in New York or other states with age limits below eighteen) who are automatically considered adults by virtue of the state age of majority. Yet it is difficult to count these groups. Records often are not kept, and arrest data rarely differentiate the subchapters in penal codes that trigger statutory exclusion.

"Back-end statistics" on youth serving sentences in adult jails and prison illustrate the consequences of all transfer mechanisms. These data provide a different picture. The number of youth under age eighteen in adult jails rose sharply through the 1990s to a high of almost 9,500 in 1999 and then leveled off to an average of just over 7,200 since 2000 . Figure 2 shows that between 1990 and 2004 there was a 208 percent increase in the number of juveniles younger than eighteen serving time in adult jails on any given day. The share of youth under age eighteen among total jail populations, however, is dropping: these youth accounted for 1.4 percent of the total population of state jails in 1994, 1.2 percent in 2000 , and 1 percent in $2004 .^{47}$
Figure 3 shows that the number of juveniles younger than eighteen admitted to state prisons nationally peaked in 1995 at approximately 7,500 and declined over the next seven years. The share of these youth among prison populations is also dropping. Youth under age eighteen accounted for 2.3 percent of the total population of state prisons in 1996, more than double the share (1.1 percent) in 2002. Since 1995, the total prison population has risen 16 percent, while the number of youth under age eighteen in prison has dropped 45 percent. ${ }^{48}$

Finally, in California, 6,629 youth were sentenced to the California Department of Corrections between 1989 and 2003 to serve sentences as adults. ${ }^{49}$ The average incarceration rate was 475 a year, but varied from a low of 172 in 1989 to a peak of 794 in 1997. In 2003, 504 minors were sentenced to adult prison in California.

Together, these front- and back-end estimates suggest that the commonly cited estimate that 210,000 youth a year are transferred to 


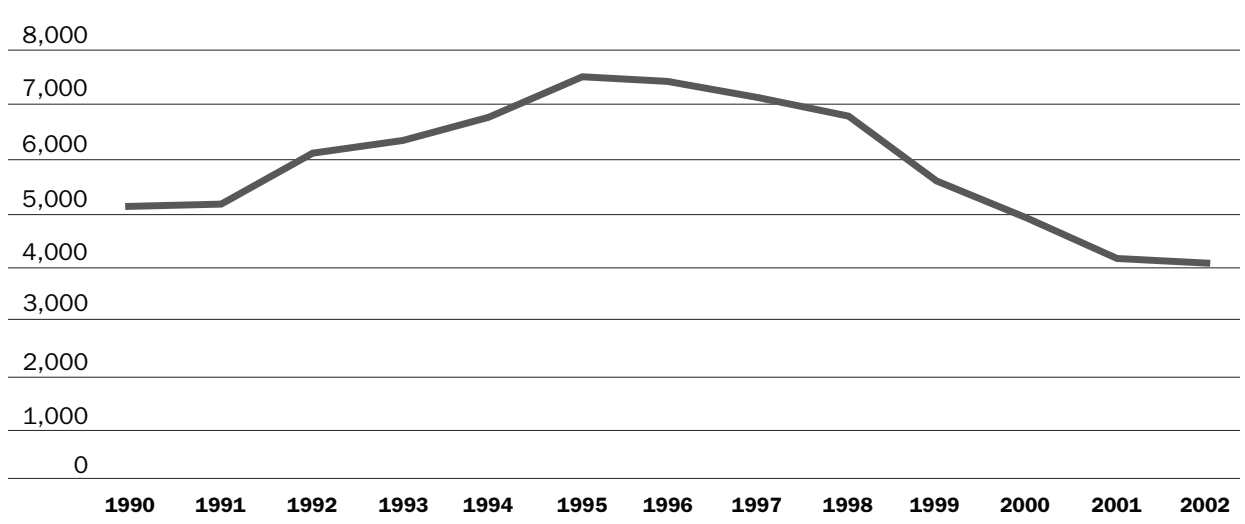

Source: H. Snyder and M. Sickmund, National Center for Juvenile Justice, Juvenile Offenders and Victims: 1999 National Report (www. ncjrs.gov/html/ojjdp/nationalreport99/toc.html [September, 1999]).

criminal court ${ }^{50}$ may be an upper bound. How much lower the estimate should be is difficult to determine, and any estimate is prone to error. What can be said is that there is substantial traffic between the juvenile and criminal courts, and most of it is one-way. And the consequences of transfer are severe. Each year tens of thousands of youth below age eighteen are newly incarcerated in prisons and jails, often together with adults, launching an experience whose irrevocable stigma clouds their future economic and social lives. By any measure, this is a large-scale social "experiment" in youth policy whose effects, as I show later, are anything but positive.

\section{Race and Transfer}

The overrepresentation of minority youth among those transferred is not surprising, given their overrepresentation at every stage of juvenile and criminal justice processing. ${ }^{51}$ Whether minority youth are overrepresented relative to their crime rates, and especially relative to the types of crimes that are enumerated in many state transfer and exclusion laws, is a more complex question, but the balance of evidence suggests that they are. ${ }^{52}$
Again, the picture of disparity varies at different stages in the juvenile and criminal justice systems. A back-end view, for example, suggests strong disparities among youth serving in prisons. In 1997, Bureau of Justice Statistics data showed that between 1985 and 1997,58 percent of the youth admitted to state prisons under eighteen years of age were black and 15 percent were Hispanic. ${ }^{53}$ The Campaign for Youth Justice ${ }^{54}$ cites data from the California Department of Corrections that in 2003, black youth were 4.7 times more likely to be transferred than white youth, and Hispanic youth 3.4 times more likely. These populations would include youth transferred judicially to criminal court, as well as those excluded by statute under Proposition 21. The same report cites Virginia Department of Corrections data from 2005 showing that black youth comprise less than 50 percent of youth arrested but more than 73 percent of youth entering adult prisons.

A front-end view suggests fewer disparities in waiver. For example, Charles Puzzanchera ${ }^{55}$ reports that 46 percent of the judicially waived population during 1990-99 was non-white. Yet most analysts duck the question 
Table 6. Index of Racial Disparity in the Juvenile Justice System, 2002

\begin{tabular}{lrrr} 
Decision points & White & Black & Relative rate index \\
\hline Juvenile arrests & $1,576,400$ & 625,000 & \\
\hline Cases referred to juvenile court & $1,086,700$ & 473,100 \\
\hline Cases detained & 199,700 & 118,600 \\
\hline Cases petitioned & 596,800 & 306,000 \\
\hline Cases judicially waived to criminal court & 4,400 & 2,500 \\
\hline Cases adjudicated delinquent & 421,400 & 179,000 \\
\hline Adjudicated cases resulting in placement & 90,400 & 47,500
\end{tabular}

Rates (per 100)

\begin{tabular}{lccc}
\hline Juvenile arrests to population* & 6.1 & 11.5 & 1.9 \\
\hline Cases referred to juvenile arrests & 68.9 & 75.6 & 1.1 \\
\hline Cases detained to cases referred & 18.4 & 25.1 & 1.4 \\
\hline Cases petitioned to cases referred & 54.9 & 64.7 & 1.2 \\
\hline Cases waived to cases petitioned & 0.7 & 0.8 & 1.1 \\
\hline Cases adjudicated to cases petitioned & 70.6 & 58.5 & 0.8 \\
\hline Placements to cases adjudicated & 21.5 & 26.5 & 1.2 \\
\hline
\end{tabular}

- For every 100 white youth ages ten to seventeen in the U.S. population, there were 6.1 arrests of white youth under age eighteen. The rate for black youth was 11.5, yielding an RRI for the arrest decision of 1.9. The black rate was almost double the white rate.

- Except for the adjudication decision point, the RRI shows a degree of racial disparity for black youth. This disparity accumulates throughout the process, so that in the end, while black youth were 16 percent of the youth population and were involved in 28 percent of the arrests of youth in 2002, they accounted for 33 percent of the juvenile court cases that resulted in an out-of-home placement.

* Population ages ten to seventeen $=25,994,400$ (white) and 5,431,300 (black).

Source: H. Snyder and M. Sickmund, National Center for Juvenile Justice, Juvenile Offenders and Victims: 1999 National Report (www. ncjrs.gov/html/ojjdp/nationalreport99/toc.html [September, 1999]).

of whether waiver is racially disproportionate to race-specific crime or arrest rates. Instead, they more often compute race differences based on earlier stages of case processing, mooting the cumulative effects of how youth of different races enter the system. As part of the federal Disproportionate Minority Confinement program, Howard Snyder and Melissa Sickmund computed a Relative Rate Index to estimate disparities at each stage of juvenile justice processing. Table 6 reproduces the chart for 2002 from their most recent report. Large disparities between black and white youth are evident at arrest and at detention. Judicially waived cases show fewer disparities. But these data are misleading in two ways. First, they filter out cumulative disadvantages by race from the outset of a case in the juvenile court-decisions in charging, detention, charge reduction, and the decision to seek waiver itself-and look only at the decision to waive. This selective filtering, or "selection bias," seriously limits understanding of race and waiver. Second, the judicial waiver data are likely underestimates that do not take into account youth excluded by statute from juvenile court jurisdiction. ${ }^{56} \mathrm{~A}$ more comprehensive data set used by Bishop, including data on all three routes of transfer, ${ }^{57}$ reports that 69 percent of the tens of thousands of youth excluded each year by statute are non-white. No estimate of racial differences in youth crime, apart from homicide, suggests that minority youth account for such a large share of crime. 
The Snyder and Sickmund report on judicial waiver also claims that race disparities are narrowing. The share of white defendant cases in juvenile court that were waived increased from 1990 to 1999 by 9 percent, while the share for black youth declined by 24 percent. This decline, however, may be an artifact of the expansion of other pathways for transfer during this period, an expansion that may have disproportionately affected minority youth who were more often arrested for laws that were the targets of legislative activism. ${ }^{58}$

The real issue, though, is not whether disparities in waiver exist because minority youth are more often involved in crime or because they are arrested at disproportionately higher rates per crime than are white youth relative to their involvement in crime. ${ }^{59}$ Rather, the essential question about race and transfer is whether there is disparate treatment given the fact of contact with the juvenile or criminal court. We might expect more black youth to be judicially waived or in adult prison relative to white youth if their offending rates are higher. But disparity might better be viewed in terms of the balance across racial and ethnic groups in the rate of transfer relative to each group's arrest rate, rather than their offending rate. This measure is akin to the ways that epidemiologists compute relative risk ratios given exposure to an agent.

There are reasons to think that these ratios are not balanced and that racial disparities in the incarceration of youth under age eighteen in state prisons cannot be explained simply by differences in offending. The racial disparities in incarceration are produced by the cumulative effects of an entanglement of discretionary processes at each stage of the juvenile and criminal justice process. Analysts consistently find evidence of selective enforcement that targets minorities well beyond what any difference in their crime rates might predict. ${ }^{60} \mathrm{~A}$ long line of studies shows how race influences police officers' decision making and judgment about suspicion and dangerousness. ${ }^{61}$ Social science evidence also suggests the banal, commonplace, and normalized influence of racial biases in everyday case processing in the juvenile and criminal courts, much of it influenced by implicit biases. ${ }^{62}$ Either directly or through surrogates and substitutes such as clothing, demeanor, neighborhood, or other racialized cues, unconscious and conscious biases influence decisions about whom to arrest and how to charge and sentence them.

\section{Either directly or through} surrogates and substitutes such as clothing, demeanor, neighborhood, or other racialized cues, unconscious and conscious biases influence decisions about whom to arrest and how to charge
and sentence them.

Evidence from other corners of criminal justice also shows the cumulative effects of racial bias, from which youth are not exempt. ${ }^{63}$ Both discretionary and statutory routes for youth to the criminal court pass through these gates. Accordingly, disparities in transfer are the product of a cumulative process that involves the systematic and cascading application of discretion across the juvenile and criminal justice systems, as well as in structural components created both by policy and law. 


\section{The Punitive Reach of Transfer}

Transfer statutes and policy typically are designed to increase the certainty, length, and severity of punishment. Leniency, or limits on penal proportionality, was one of the lightning rods for those hostile to the juvenile court who advocated for tougher measures for juvenile crime. The evidence, however, suggests that these advocates only partially achieved their goals and that they put in place a far more complex and contingent pattern of sentencing and punishment than they might have anticipated.

Several studies illustrate the variability and contingencies in sentencing of transferred cases in the criminal courts. For example, Martin Roysher and Peter Edelman ${ }^{64}$ showed $^{2}$ in the 1970s that sanctions were no more severe in criminal court than in juvenile court in the years immediately following passage of the JO Law in New York; in many cases, and in some upstate counties, sentences were less harsh. Over time, research in different locales by Kay Gillespie and Michael Norman, by Dean Champion, and by Barry Feld, all showed similar patterns ${ }^{65}$ Contrary to the retributive intent of waiver, Marilyn Houghtalin and Larry Mays showed that juveniles are sanctioned less severely in criminal court than are their counterparts in juvenile court, through relatively lenient sanctions and higher case attrition. ${ }^{66}$ In 1984 Peter Greenwood and several colleagues offered several explanations why adolescents might face more lenient sanctions in criminal court, ${ }^{67}$ and, based on recent studies in Florida, Minnesota, and New York, these explanations seem accurate today. Young offenders in criminal court may appear less threatening-physically smaller and younger, shorter criminal records-than their older counterparts with longer records. Moreover, even though juvenile records are unshielded legally in many jurisdictions, Barry
Feld showed that the juvenile's criminal history often may be unavailable to the criminal court because of the functional and physical separation of juvenile and criminal court staffs who must compile and combine these records and, sometimes, because of sheer bureaucratic ineptitude..$^{68}$ As a result, the same juvenile recidivist who appears incorrigible to the juvenile court may appear to the criminal court to be a less chronic and less serious offender. However, many states have removed these shields, and juvenile records are now routinely considered in criminal court.

But more recent studies show that the leniency gap has been reversed. In the Florida studies, Donna Bishop and her colleagues reported that youth charged with violent crimes were more likely to be incarcerated if sentenced in the adult court. ${ }^{69}$ Aaron Kupchik and several colleagues showed a similar pattern comparing structured sentencing of transferred youth in New York with discretionary sentencing of youth in the juvenile court in New Jersey.$^{70}$ In many jurisdictions, structured sentencing determines the disposition in criminal court: the seriousness of a young adult's present offense and adult criminal history are the calculus of sentencing. This is one reason why nearly one-third of youth aged sixteen and seventeen in New York with no previous record were sentenced to adult prison under the New York JO Law. ${ }^{71}$ This figure reflects the emphasis on violent crimes in expanded transfer laws and procedures across the states. National trends on judicial waivers show that adolescents charged with and waived for violent crimes receive substantial sentences as adults. ${ }^{72}$ Local studies show the same. For example, Cary Rudman and several colleagues, looking only at adolescents charged with violent crimes in four jurisdictions, found that the criminal court was more punitive. ${ }^{73}$ The likelihood of 
incarceration was the same in juvenile and criminal court, but juveniles waived to criminal court received longer sentencesalmost always in adult prisons-because there was no upper age boundary for incarceration. Barry Feld and Marcy Podkopacz found that waived youth in Minneapolis received longer sentences for violent crimes, but shorter sentences for property crime, than retained youth. ${ }^{74}$ Fagan, comparing sentences in New York and New Jersey for offenders aged fifteen and sixteen in 1981-82, found that youth adjudicated on robbery or assault in adult rather than juvenile court were more likely to be incarcerated and received longer sentences. ${ }^{75}$ But in a second study of juveniles sentenced five years later in the same two courts, the gap between juvenile and criminal court sanctions had narrowed significantly.

Thus, the age-offense relationship apparently produces a peculiar disjunction in the sentences of juveniles as adults. When sentenced as adults, young property offenders may receive shorter sentences than do their juvenile counterparts, though young violent offenders may receive dramatically longer sentences and under more punitive conditions than do their juvenile counterparts.

\section{Comparative Correctional Experiences}

What little research there is on the correctional experiences of transferred youth has focused on transferred youth who are locked up in state prisons. Little is known about the short stays of such youth in county jails. Nothing is known about how they experience probation supervision, including whether they are linked to services that can help them avoid a return to crime. Nor is anything known about how youth receiving blended sentences, or contingent punishment, experience their two-stage correctional stays. Likewise, for youth released from prison, little research charts their re-entry experiences and outcomes. More research is needed about all these areas of transfer policy to fully understand why transfer itself, not just the experiences of the group that goes to adult prison, seems to produce worse outcomes.

\section{Few modern criminologists or correctional administrators maintain the illusion that incarceration has either broad therapeutic benefits or a strong deterrent effect.}

As I show later, incarceration does explain the higher recidivism rates of transferred youth. Why should their correctional experiences matter? There are two reasons. The first is that the primary thrust of transfer laws was to increase the length and severity of punishment. A serious assessment of transfer as a policy must engage its retributive component. One impulse behind transfer activism, fed by the popular perception that the juvenile court's punishment tools were mismatched to the increasing severity of youth crime, was to challenge the juvenile court to attain proportionality in the length and severity of its punishments. A careful analysis of transfer, then, should consider the quality of retribution and the possibility that, for adolescents, lengthy stays in harsh conditions of confinement can be disfiguring, with unknown developmental costs.

Comparisons of juvenile and adult correctional settings suggest that youth in prisons face higher risks of violence. Martin Forst and several colleagues showed how the sharp policy and atmospheric differences between 
the security orientation in adult prisons and the therapeutic and educational orientations of juvenile facilities translate into serious consequences for safety and mental health. ${ }^{76}$ They compared the experiences of 140 youth in adult and juvenile facilities over four locales. Youth in adult prisons reported higher rates of physical and sexual assault than did matched samples of youth in juvenile corrections. Using standardized scales, youth in juvenile settings reported that staff was more involved and helpful in social and behavioral services. They reported stronger educational programs and employment training and rated therapeutic case management services higher. They also noted that staff in the juvenile facilities were far more attentive to building and strengthening ties to family and other social networks that would be influential on release. ${ }^{77}$ Bishop and Frazier reported nearly identical responses in their Florida sample.

In a replication a decade later, Fagan and Kupchik found fewer differences in victimization than did Forst and his colleagues. ${ }^{78}$ In fact, juvenile facilities appeared to be more chaotic, with higher levels of drug use and self-reported offending and victimization. But youth in adult prisons nevertheless felt less safe and reported significantly more symptoms of mental illness and post-traumatic stress disorder. Even in the more outwardly stable contexts of adult prisons, where the social organization is maintained by rigid inmate networks, the perceptions and consequences of being surrounded by cohorts of older, often violent, inmates produced stronger feelings of insecurity and collateral mental health consequences.

A second reason why correctional experience should matter is one of principle. The corrective component of punishment often is invoked to justify its effects, yet incarceration seems to have little correctional effect. Few modern criminologists or correctional administrators maintain the illusion that incarceration has either broad therapeutic benefits or a strong deterrent effect. ${ }^{79}$ Recidivism rates in adult prisons are simply too high-more than two prisoners in three released in 1994 returned to prison within three years ${ }^{80}$ - to sustain beliefs in either the rehabilitative or deterrent component of adult corrections. What is the principle, and corresponding youth policy, that mandates exposure to conditions that are likely to produce failure, a failure with perhaps lasting impacts on an adolescent's social development and wellbeing far into the life course? We already know that incarceration experiences in adolescence radically curtail social, economic, and psychological development over the life course. ${ }^{81}$ Do incapacitation or retribution concerns justify such costs? These policy goals tell us what to punish and perhaps whom, but they do not inform a policy of how to punish.

\section{The Public Safety Effects of Transfer Laws}

Research on the deterrent effects of transfer on public safety focuses on both general and specific deterrence. Most of the evidence on general deterrence suggests that laws that increase the threat of sentencing and incarceration as an adult have no effect on youth crime rates. Research on specific deterrence consistently finds that adolescent offenders transferred to criminal court have higher rates of re-offending than do those retained in juvenile court. Rarely do social scientists or policy analysts report such consistency and agreement under such widely varying sampling, measurement, and analytic conditions.

\section{General Deterrence}

Researchers investigating general deterrence 
typically estimate differences in rates of offending by adolescents under varying sanctioning and punishment regimes. Study designs to test general deterrent effects sort into two approaches. Most studies use time series methods, comparing crime rates before and after the passage of laws lowering the age of majority for specific categories of offenses and offenders. Others compare youth crime rates in states with different statutory boundaries for the age of majority. Both types of studies often use econometric models to compare age-specific crime rates for states with different age thresholds for criminal court eligibility, statistically controlling also for punishment contingencies and other covariates of crime and justice system performance. The evidence tips against the claim that youthful offenders are sensitive to the age boundaries that make them eligible for punishment in the criminal courts. The consensus cuts across studies that vary in study designs, time periods, locales, and methods of analysis.

Most general deterrence studies find that offending rates among adolescents either remain unchanged or increase once they reach age-defined eligibility for the criminal court. Simon Singer and David McDowall reported no general deterrent effects when New York State passed the JO Law in 1978, despite widespread publicity and enforcement of the law statewide. ${ }^{82}$ That finding is surprising, because young people in New York evidently were well aware of the law, a fundamental prerequisite for deterrence. ${ }^{83}$ Nevertheless, the findings were mixed, especially among older cohorts of youth who were closer to the age of majority. The results were uneven across the state, as well, with little effect on youth crime rates in the highercrime areas, including New York City.
Two other single-state studies - one in Idaho and one in Washington-reported similar findings. Eric Jensen and Linda Metsger used time series analysis to estimate differences in juvenile crime rates three years before and five years after Idaho passed a law that mandated transfer for youth aged fourteen to seventeen charged with any of five violent crimes. Juvenile crime rates in Idaho actually rose after the law was passed, while crime rates in neighboring states were declining. ${ }^{84}$ Robert Barnowski used time series models to estimate changes in juvenile crime rates before and after passage of Washington's 1994 Violence Reduction Act and a 1997 amendment expanding the law. He analyzed juvenile arrest rates for youth aged ten to seventeen from 1989 to 2000 and compared state trends with national trends. He found no differences in the two trends; juvenile arrest rates for the target crimes peaked in 1994 for each. ${ }^{85}$

Only one study, by Steven Levitt, reported that adolescent offenders are sensitive to the age boundary for adult punishment. Levitt estimated significantly lower age-specific crime rates for adolescents between 1978 and 1993 in states where the age of majority was seventeen than in states where offenders were eligible for criminal court at age eighteen. ${ }^{86}$ But the finding was not true across the board: the effects of jurisdictional age were conditioned on the comparative likelihood of incarceration in the respective courts. Juvenile crime rates were lower in states with higher juvenile incarceration rates, and marginal increases in the juvenile incarceration rate had greater leverage on juvenile crime rates than did the age of jurisdiction. Levitt's analysis suggests that strengthening the correctional response in the juvenile system can improve public safety without exacting the social and crime costs of transfer. 
Across all these studies, the great majority of the evidence agrees that young offenders seem unresponsive to sharp changes in the risk of harsher penalties and that the age at which they are exposed to these penalties seems to matter little if at all. The appetites of adolescents for crime and its rewards seem invariant to punishment threats. David Lee and Justin McCrary characterize young offenders as myopic, unfazed by the threat of short prison sentences and discounting the consequences and likelihood of longer ones. ${ }^{87}$ It is hardly unreasonable to assume that knowledge of changes in the law diffuses efficiently through adolescent peer networks that are, in effect, information markets to manage a variety of adolescent risk behaviors. ${ }^{88}$ Yet in these highly localized and efficient networks, teens seem to discount changes in the law's consequences in a manner that typifies adolescent reasoning and planning. A generalized change in the risk environment seems unable to leverage changes in behavior.

\section{Specific Deterrence}

As a policy matter, the critical test for transfer is whether it enhances public safety. Recent research on transfer suggests that, for youth with comparable individual characteristics and correctional experiences, recidivism rates are either the same or significantly higher for transferred youth than for youth retained in the juvenile court. Accordingly, studies on the specific deterrent effects of criminal court sanctions show no evidence of public safety benefits from transfer.

Another single-state study, in Florida, combined age of majority and changes in sanctioning probabilities to estimate the effects of reaching the age of majority on age-specific crime rates. Lee and McCrary used panel methods to estimate the probabilities of rearrest for a sample of youth arrested before age seventeen between 1989 and 2002 in Florida. ${ }^{89}$ The authors constructed complete criminal histories going back to the date of first arrest and tracked them over time, controlling for punishment experiences. Again, they found little change in offending rates once youth turned age eighteen and faced more severe and longer terms of punishment as adults. They also found no effects of transfer to criminal court. They concluded that none of the mechanisms to toughen punishment for adolescentswhether transfer to criminal court, or longer sentences or even aging out of the juvenile jurisdiction—show marginal deterrent effects.

\section{The Task Force on Community Preventive} Services, a standing committee including policy experts from government, academia, and private research, reviewed seven studies and concluded that youth transferred to adult court subsequently commit violent crime at higher rates than do those retained in juvenile court. ${ }^{90}$ Figure 4, which is taken from the Task Force report, illustrates graphically the range of the effects of transfer on recidivism in several of the studies. Some studies suggest that transfer to the criminal court worsens criminal behavior and increases public safety risks. Again, the consistency of the findings, across a variety of sampling, measurement, and analytic conditions, is rare in policy science.

The studies typically compared court outcomes and recidivism rates for matched groups of transferred and retained youth. Some studies compared the criminal records of similar groups of youth either from the same time period or from different time periods before and after law changes. ${ }^{91}$ Some studies used designs that are similar to experiments to compare waived and retained youth. These designs are approximations of true experiments, where the youth in juvenile 
Figure 4. Comparison of Effects of Transfer on Recidivism Rates in Five Studies of Specific Deterrence

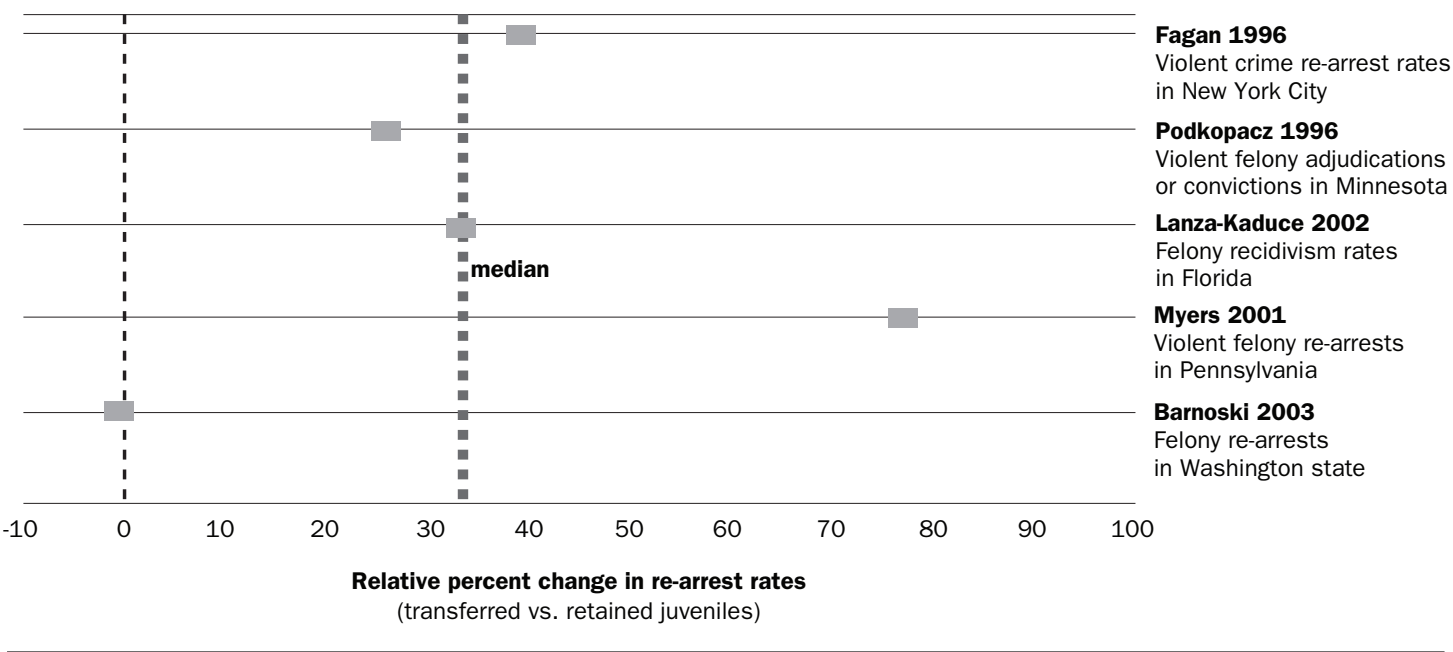

Note: Effects of transfer on re-arrests of transferred juveniles. (Results of one other study were not presented here because of complex effect modification by initial offense and other status characteristics.)

Source: For detailed citations to these studies, see Andrea McGowan and others, "Effects on Violence of Laws and Policies Facilitating the Transfer of Juveniles from the Juvenile Justice System to the Adult Justice System: A Report on Recommendations of the Task Force on Community Preventive Services," Morbidity and Mortality Weekly Report 56, no. RR-9 (November 30, 2007).

and criminal court are matched on several factors, such as the number and severity of prior offenses, and then compared on their criminal records after they are sentenced and punished. Other studies compared youth from adjoining jurisdictions with different statutes. ${ }^{92}$ The studies also vary in how they test the effects of the different court jurisdictions. Most limit their tests to a simple test of what happens in one court compared with the other, while some others control for what court the case is heard in and what correctional sentence the youth receives. The outcome measures sometimes are specific crimes, such as violence or drug offenses, and sometimes all types of crimes. The studies vary in the lengths of the follow-up periods, with some reporting short-term differences that disappear after several years. ${ }^{93}$

How confident can we be in these studies and the conclusions of the Task Force? Some critics of these studies think that there are weaknesses in the designs that may undermine the conclusions. For example, most of the studies introduce selection biases that prevent a true comparison of the two types of proceedings and sanctions. That is, the process of selection for transfer-whether judicial, prosecutorial, or legislative-may be based on pre-existing indices for criminal propensity that may then affect the outcomes. Accordingly, differences in the samples may reflect more about that pre-existing propensity than about the differential effects of court jurisdiction. Also, comparisons from one court jurisdiction to the next may introduce important contextual influences that may interact with the deterrent effects of punishment. ${ }^{94}$

Only a portion of the studies cited by the Task Force addressed these selection issues. Two studies of youth in Florida used different 
procedures to control for selection. Lawrence Winner and several colleagues matched cases in the juvenile and adult courts on seven criteria. ${ }^{95}$ The use of matching routines adds confidence to these studies and reflects well on the consistency of their findings with those of other studies lacking rigorous controls. ${ }^{96}$

Matches were successful for the first six variables, but transfers including matches by race were less successful. Only two-thirds of the white transfers could be matched to white non-transfers, and only about half of the nonwhite transfers could be matched to non-white non-transfers. When the race criterion was relaxed, successful matches were obtained in 92 percent of the cases. There were no controls for court or community context. Lonn Lanza-Kaduce and several colleagues ${ }^{97}$ computed a risk index based on twelve items and used propensity score matching to adjust for selection effects in the transfer process. He was able to match 475 pairs overall and 315 "best matched pairs" that excluded transferred youth whose criminal history was longer or more severe than a matched contemporary in the retained sample. The differences in recidivism rates using these two design strategies produced similar results that both show substantially higher recidivism rates for transferred youth, particularly in the initial three to five years following sentencing.

A study by Fagan and another by Fagan and two colleagues compared recidivism rates among samples of youth recruited from New York City whose cases originated in the criminal court with samples from bordering areas in northeastern New Jersey whose cases were processed in the juvenile court. ${ }^{98}$ In each study, the researchers estimated a selection parameter, or a "propensity score," to control for differences in the samples. ${ }^{99}$ The propensity score was included as a predictor in the analyses of recidivism rates.
Even among the few studies that address selection issues, findings are consistent and strong. When joined with other studies showing similar findings, they offer robust evidence of the perverse effects of both wholesale and retail transfer to the criminal court. Moreover, these studies reject the notion that these effects are limited to the subset of transferred youth who are incarcerated in adult prisons. Fagan and Fagan and colleagues as well as Lee and McCrary, specifically test for incarceration effects and find no evidence that either the fact of incarceration or its length significantly predicts recidivism. Several other studies made similar findings. Increasing the risk or length of confinement offers no return to crime control for transferred youth.

\section{Summary}

In her review of two decades of research on transfer, Donna Bishop condemns the "recent and substantial expansion of transfer" as harmful and ineffective. ${ }^{100}$ Richard Redding says that " $\mathrm{t}]$ he short-term benefits gained from transfer and imprisonment may be outweighed by the longer-term costs of (increased) criminal justice system processing" from higher recidivism rates. ${ }^{101}$ Without exception the research evidence shows that policies promoting transfer of adolescents from juvenile to criminal court fail to deter crime among sanctioned juveniles and may even worsen public safety risks. The weight of empirical evidence strongly suggests that increasing the scope of transfer has no general deterrent effects on the incidence of serious juvenile crime or specific deterrent effects on the re-offending rates of transferred youth. In fact, compared with youth retained in juvenile court, youth prosecuted as adults had higher rates of rearrest for serious felony crimes such as robbery and assault. They were also rearrested more quickly and were more often returned to incarceration. 
Worse, the broad reach of new transfer laws and policies captures not only those youth whose crimes and reoffending risks may merit harsher punishment, but also many more who are neither chronic nor serious offenders, who pose little risk of future offending, and who seem to be damaged by their exposure to the adult court. Whatever the gains of short-term incapacitation, they are more than offset by the toxic effects of adult punishment for the larger group of adolescent offenders.

\section{Principles for Transfer Policy}

The proliferation of promiscuous transfer regimes over the past three decades calls into question the very rationale for a juvenile court. The new legislative activism has rolled back the age at which maturity is assumed to a threshold that strains the credibility of the new laws themselves. But there is almost no evidence that justifies this decades-long experiment.

\section{Three Strikes against the New Transfer}

All scientific evidence suggests that transferring early adolescent youth to adult courts inverts assumptions about their cognitive and behavioral capacities before the law and in nearly every other age-graded social task. Wholesale transfer laws such as New York's JO Law or California’s Proposition 21 assume a level of maturity and responsibility among young adolescents that is sharply at odds with new social and scientific facts. To be sure, retributive interests benefit from wholesale transfer regimes, but at the cost of vastly multiplying the number of individual injustices from proportionality miscalculations. ${ }^{102}$

The new transfer measures fail to enhance public safety, despite repeated assertions to the contrary by prosecutors and legislators. Instead, prosecuting adolescents as adults, no matter what the pathway to adult court, leads to more, not less, crime, inviting avoidable public safety risks. More youth, it is true, are incapacitated for longer periods once in the criminal court - in many instances, for the rest of their lives. Yet there is no evidence that incarcerating minors for any length of time deters crime either by those locked up or by others.

\section{Without exception the}

research evidence shows that

policies promoting transfer of adolescents from juvenile to criminal court fail to deter crime among sanctioned juveniles and may even worsen public safety risks.

Had the large-scale legal mobilization to increase transfer been subject to federal (and university) standards for the ethical treatment of human subjects, it would have been shut down long ago. One might argue that the benefits of penal proportionality and incapacitation justify the overreach in moving youth to adult court, but even here, the calculus fails. Transfer, whether retail or wholesale, runs a high risk of exposing to harm not just its subjects, but also the public that hosts these measures. These harms are multiplied by the corrosive effects of a criminal record on the possibility of reformation or prosocial development. A transfer regime calibrated at age seventeen may overreach or underreach at the margins, but transfer policies that move youth into criminal court at age sixteen will categorically be overreaching and 
weighted toward over-punishment. These policies endure in the face of good evidence of the possibility of such harms, perhaps animated by deep biases about youth among legislators if not the public. ${ }^{103}$ The racial skew in transfer and its effects, a result in part of the conflation of youth crime and race in the popular and political imagination, ${ }^{104}$ multiplies the ethical tensions in transfer policy.

\section{The Politics of Transfer and the Politics of Crime}

Policymakers have taken notice of the robust evidence on the negative effects of transfer, creating a political space for reform as advocates and reformers have pushed back against expanded transfer. Connecticut passed legislation in July 2007 to raise the age of majority incrementally from age sixteen to age eighteen by 2010 . In the past two years, legislators in Missouri, Illinois, and New Hampshire have had extensive debates over whether to raise the age to eighteen. Legislators in North Carolina have convened hearings and formed a study commission to address this issue. ${ }^{105}$ The debates focus less on whether to raise the age than on the strategies and details of how to do so effectively. The research evidence on transfer and the decrease in serious juvenile crime have convinced most legislators, policymakers, practitioners, and other stakeholders that eighteen may yet again be the appropriate age for juvenile court jurisdiction.

Reformers face a difficult task. Transfer and youth policy raise complex questions that are not just about youth crime. Transfer is one front in a longstanding tension between the judiciary and other branches of government during successive legislative efforts to control crime. It is also an important symbolic front in showing toughness on crime. The general hostility toward judges that was evident in the overall narrowing of judicial discretion-such as the adoption of sentencing guidelines for adults that set minimum or fixed sentencesalso extended to the juvenile court, where measures to expand transfer curtailed judicial discretion. The sharp restriction of judicial authority in favor of enhanced prosecutorial power (as in Proposition 21) or legislative authority (as in the New York JO Law) resulted in the expansion of prosecutorial power at the expense of judicial authority. The accretion of authority to prosecutors in this regime is clear: the prosecutor has the unreviewable discretion to select charges and, in turn, to select jurisdiction. Although direct file provisions offer some degree of transparency, exclusion statutes (which account for a large number of transfers) offer none.

\section{Restoring Principle to the Transfer Debate}

The debate about transfer to date has been based neither on principle nor on policy, but on the need for "toughness." 106 It is about the substitution of toughness for principle. No scholar or practitioner or advocate denies that it is sometimes necessary to transfer some adolescents to criminal court. The public must be protected from dangerous youth who are not likely to be helped by treatmentoriented or supervisory sanctions. An unrebuttable assumption of immaturity for all robbery suspects younger than age eighteen would be as silly as an unrebuttable assumption of their maturity at fourteen. But delinquent youth also must be protected from the overreach of wholesale waiver. And the reduced decision-making capacity of juveniles provides a principled justification for finetuning the borders of the juvenile justice system to avoid unnecessary risk.

Setting these boundaries poses a dilemma for lawmakers that they simply ignore when 
they retreat to the simplistic overreach of legislative exclusion or cede discretion to (elected) prosecutors. Developing transfer policy, both calibrating the threshold itself and devising the mechanism for crossing it, involves weighing competing risks. Two types of error lie in wait. One is overpredicting the likelihood of juveniles' offending. The other is underpredicting recidivism risks. The two types of predictions are linked, and evaluating waiver or transfer as public policy requires considering both types of risk. Such is the ethical responsibility of the regulator. ${ }^{107}$

Principles for transfer can produce hard choices and conflicting results. A legislative waiver regime may produce fewer racial disparities for youth under the criminal law than does individual waiver by judges. But legislative waiver raises substantial risks and social costs. ${ }^{108}$ Are longer sentences in the juvenile court preferable to shorter sentences in the criminal courts? When we pile on redundant reforms-blended sentences, presumptive transfer, longer juvenile court sentences-do the cumulative and cascading effects produce the intended consequences, or does some less desirable outcome develop?

The future of reform depends on the prospects for restoring principle and discipline to the legislative debate. The weight of evidence points toward returning to juvenile court judges the discretion to select juveniles for transfer. The evidence also points toward basing that selection on more criteria than age and offense. Using Kent-like criteria and new scientific knowledge of adolescent development in an open and transparent forum, judges, who are less influenced than legislators by the politics of crime and by electoral pressures, should be able to decide which adolescents should be transferred. ${ }^{109} \mathrm{~A}$ jurisprudence of discretionary decision making on transfer would also promote two ancillary goals. It would restore the accountability that is diffused when legislators surgically remove entire classes of offenders from the juvenile court. And it would take seriously the responsibility for mistakes on both sides of the decision threshold.

Returning to discretionary transfer rather than "wholesale waiver" also would minimize harm by limiting the number of youth subjected to criminal court prosecution while identifying those whose plasticity warrants juvenile court intervention. Yet it would also maintain proportional punishment for adolescents whose crimes are too serious to be adjudicated in the juvenile court.

A now extensive portfolio of empirical research suggests that past attempts to select youth individually for transfer have often failed to identify the most serious offenders and have also reinforced racial discrimination. ${ }^{110}$ More careful screening is crucial. New evidence on the dangers of wholesale transfer suggests that the ethical regulator must balance the risk of two types of error, not just the risks of leniency that motivate contemporary statutes and practices. Strong commitments to transparency and ongoing analysis of the patterns and rationales for such decisions can enable judges and other juvenile justice stakeholders to calibrate where the borders should be set and to track and measure the performance of those making transfer decisions.

Declining crime rates, the intellectual and political exhaustion of the "toughness" paradigm in juvenile justice, and new gains in the science of adolescent development have converged to create an opportunity for reform. Opening the transfer process to regulation and deliberation can lay the foundation for 
more effective and principled policies. While the law has moved toward waiving increasingly younger teens to adult criminal court, social and biological evidence suggests moving in the other direction. Perhaps it's time for the law to change course and follow the science. 


\section{Endnotes}

1. David Tanenhaus, Juvenile Justice in the Making (Oxford University Press, 2004); see Judith Sealander, The Failed Century of the Child: Governing America's Young in the Twentieth Century (Cambridge University Press, 2003); Anthony Platt, Child Savers: The Invention of Delinquency (University of Chicago Press, 1967).

2. Tanenhaus, Juvenile Justice in the Making (see note 1).

3. Kent v. U.S., 383 U.S. 541 (1966). The Kent guidelines were an amalgam of administrative rules and norms of everyday practice. States quickly adopted the Kent guidelines into law.

4. Time, "The Youth Crime Plague," July 11, 1977; Newsweek, “The Drug Gangs,” March 28, 1988; William J. Bennett, John DiIulio Jr., and John P. Walters, Body Count: Moral Poverty and How to Win America's War against Crime and Drugs (New York: Simon and Schuster, 1996).

5. David Garland, Punishment and Welfare (University of Chicago Press, 1990); Jonathan Simon, Governing through Crime (Oxford University Press, 2007); Michael Tonry, Malign Neglect: Race, Crime, and Punishment in America (University of Chicago Press, 1996); Michael Tonry, Thinking about Crime: Sense and Sensibility in American Penal Culture (Oxford University Press, 2004).

6. Barry C. Feld, Bad Kids: Race and the Transformation of the Juvenile Court (Oxford University Press, 1999); Simon Singer, Recriminalizing Delinquency: Violent Juvenile Crime and Juvenile Justice Reform (Cambridge University Press, 1996).

7. Singer, Recriminalizing Delinquency (see note 6); Jeffrey Fagan and Franklin E. Zimring, eds., Changing Borders of Juvenile Justice: Transfer of Adolescents to the Criminal Court (University of Chicago Press, 2000).

8. Feld, Bad Kids (see note 6).

9. Andrea McGowan and others, "Effects on Violence of Laws and Policies Facilitating the Transfer of Juveniles from the Juvenile Justice System to the Adult Justice System: A Report on Recommendations of the Task Force on Community Preventive Services," Morbidity and Mortality Weekly Report 56, no. RR-9 (November 30, 2007): 1-11; Donna Bishop, "Juvenile Offenders in the Adult Criminal System," Crime and Justice: A Review of Research 27 (2000): 81-167.

10. See Fox Butterfield, All God's Children: The Bosket Family and the American Tradition of Violence (New York: Harper Perennial, 1995), for a detailed account of the shooting, its political context, and the legislative reaction. See, also, Merrill Sobie, "The Juvenile Offender Act: Effectiveness and Impact on the New York Juvenile Justice System,” New York Law School Law Review 27 (1981): 677-91.

11. Martin Roysher and Peter Edelman, "Treating Juveniles as Adults in New York: What Does It Mean and How Is It Working?" in Major Issues in Juvenile Justice Information and Training, ed. J. C. Hall and others (Columbus, Ohio: Academy for Contemporary Problems, 1981).

12. New York Penal Law $\$ 30.00$. Connecticut and North Carolina, at that time, were the others. Connecticut has since raised the age of majority for nearly all juvenile offenders to eighteen. Connecticut General Statutes \$1-1d; North Carolina General Statutes § 7B-1501(7).

13. Roysher and Edelman. "Treating Juveniles as Adults" (see note 11); Sobie, "The Juvenile Offender Act" (see note 10). 
14. Barry Feld, "The Juvenile Court Meets the Principle of the Offense: Punishment, Treatment, and the Difference That It Makes," Boston University Law Review 69 (1988): 821-952.

15. The family court has jurisdiction over delinquency cases in New York State.

16. A fourteen-year-old offender in New York who snatches a chain from another person could be charged with robbery in the third degree and remain in the family court; if there was any use of force or threat, the offender could be charged with robbery in the second degree and fall subject to the Juvenile Offender Law, regardless of prior record or impact on the victim. The discretion lies solely with the prosecutor, whose decision is not reviewable. Similar differences exist under the JO Law for assault in the second degree.

17. See Office of Juvenile Justice and Delinquency Prevention, "Program Report," Juvenile Justice Reform Initiatives in the States 1994-1996, p. 41 (www.ncjrs.gov/pdffiles/reform.pdf [October, 1997]). Office of Juvenile Justice and Delinquency Prevention, "Juvenile Justice Bulletin," State Legislative Responses to Violent Juvenile Crime: 1996-1997 Update, p. 2 (www.ncjrs.gov/pdffiles/172835.pdf [November, 1998]). In 1998, Indiana lowered the age from sixteen to ten. During this time, twenty-two states and the District of Columbia set no minimum age at which a judge may transfer a juvenile to criminal court. Office of Juvenile Justice and Delinquency Prevention, "Report," Trying Juveniles as Adults in Criminal Court: An Analysis of State Transfer Provisions, pp. 15-16 (www.ncjrs.gov/pdffiles/172836.pdf [December, 1998]).

18. See Donna Lyons, National Conference of State Legislatures, "State Legislature Report," 1995 Juvenile Crime and Justice State Enactments 20, no.17 (November 1995). In 1995, Alaska, Arkansas, Delaware, Indiana, Louisiana, Minnesota, North Dakota, Oregon, Tennessee, Utah, and West Virginia added offenses for discretionary or mandatory juvenile prosecution in adult criminal court. Arkansas, Idaho, Iowa, Nevada, and Ohio enacted laws that made transfer permanent—so called "once waived, always waived" legislation—regardless of the outcome of the case in criminal court. Other states lowered the age at which juveniles may be prosecuted in criminal court. For instance, Idaho passed legislation providing for waiver of juveniles under age fourteen who commit certain felonies. Nevada lowered from sixteen to fourteen the age at which juveniles are subject to discretionary judicial waiver. West Virginia also lowered from sixteen to fourteen the age of discretionary transfer for certain juveniles charged with serious crimes. However, only two states took the simpler step of lowering the age of majority for all adolescent offenders. New Hampshire and Wisconsin lowered the maximum age of original juvenile court jurisdiction from seventeen to sixteen.

19. Richard E. Redding and James C. Howell, "Blended Sentencing in American Juvenile Courts," in Changing Borders of Juvenile Justice, eds. Fagan and Zimring (see note 7). See also Barry C. Feld and Marcy Rasmussen Podkopacz, “The Back-Door to Prison: Waiver Reform, 'Blended Sentencing,' and the Law of Unintended Consequences," Journal of Criminal Law and Criminology 91, no. 4 (2001): 997-1072.

20. 383 U.S. 541 (1966).

21. See, for example, Barry C. Feld and Marcy Rasmussen Podkopacz, "The End of the Line: An Empirical Study of Judicial Waiver," Journal of Criminal Law and Criminology 86, no. 2 (1996): 449-92. For a review, see Redding and Howell, "Blended Sentencing" (see note 19).

22. Feld and Podkopacz, "The End of the Line" (see note 21).

23. Patricia Torbet and others, Office of Juvenile Justice and Delinquency Prevention, State Responses to Serious and Violent Juvenile Crime, p. 3 (www.ncjrs.gov/pdffiles/statresp.pdf [July, 1996])). 
24. Jeffrey Fagan and Valerie West, "The Decline of the Juvenile Death Penalty: Scientific Evidence of Evolving Norms," Journal of Criminal Law and Criminology 95 (2005): 427.

25. Bishop, "Juvenile Offenders in the Adult Criminal System" (see note 9).

26. David Rosen, Philadelphia Defender Association, personal communication. Representation for these youth is provided by each county. Not every jurisdiction has the resources to provide defense representation that can motion for reverse waiver, and disparities arise when access to services is limited by economic resources. See Laval S. Miller-Wilson and Patricia Puritz, Pennsylvania: An Assessment of Access to Counsel and Quality of Representation in Delinquency Proceedings (www.jlc.org/File/publications/ paassessment.pdf [October 2003]).

27. Jeffrey Fagan, "Separating the Men from the Boys: The Comparative Impacts of Juvenile and Criminal Court Sanctions on Recidivism of Adolescent Felony Offenders," in Sourcebook: Serious, Violent, and Chronic Juvenile Offenders, eds. James C. Howell and others (Thousand Oaks, Calif.: Sage, 1995).

28. Stephen J. Morse, "Immaturity and Responsibility," Journal of Criminal Law and Criminology 88 (1998): 15.

29. Franklin Zimring, "Penal Proportionality for the Young Offender: Notes on Immaturity, Capacity, and Diminished Responsibility," in Youth on Trial: A Developmental Perspective on Juvenile Justice, edited by Robert Schwartz and Thomas Grisso (University of Chicago Press, 2000).

30. Barry C. Feld, "Abolish the Juvenile Court: Youthfulness, Criminal Responsibility, and Sentencing Policy," Journal of Criminal Law and Criminology 88 (1997): 68. Feld advanced the concept of a "youth discount" on adult sentences, standardizing immaturity strictly by age.

31. N. Dickon Reppucci, “Adolescent Development and Juvenile Justice," American Journal of Community Psychology 27, no. 3 (1999): 307-26; Laurence Steinberg and Elizabeth Scott, "Less Guilt by Reason of Adolescence," American Psychologist 58, no. 12 (2003): 1009-18.

32. 543 U.S. $551(2005)$.

33. Ibid.

34. Ibid. The Court's majority also said these same qualities are the reasons why juveniles are not permitted to vote, serve on juries, or marry without parental consent. It effectively contradicted Justice Scalia’s majority opinion in Stanford and recent empirical work emphasizing variability in developmental trajectories for different decisional competencies. See Steinberg and Scott, "Less Guilt by Reason of Adolescence” (see note 31$)$.

35. Ibid.

36. Brief of American Psychiatric Association as Curiae at 2-3, in Roper v. Simmons 543 U.S. 551 (No. 06-633).

37. Ibid.

38. See the article by Laurence Steinberg and Elizabeth Scott in this volume for a review of the scientific evidence on child and adolescent development and culpability.

39. See the article by Edward Mulvey and Anne-Marie Leistico in this volume. 
40. Elizabeth Cauffman and Laurence Steinberg, “( $\mathrm{Im})$ Maturity of Judgment in Adolescence: Why Adolescents May Be Less Culpable than Adults," Behavioral Sciences and the Law 18 (2001): 741-60.

41. But see Schall v. Martin, 467 U.S. 253 (1984), in which Justice Powell, writing for the majority, set aside controversial social science evidence on predictions of dangerousness and said that judges were best suited to make these determinations.

42. For example, New York and North Carolina set the age of majority at sixteen; youth in criminal court in those states should not be part of an estimate of the transferred population. But youth excluded by statute at age sixteen in other states should be measured as part of the transferred population.

43. Bishop, "Juvenile Offenders in the Adult Criminal System" (see note 9).

44. Campaign for Youth Justice, The Consequences Aren't Minor: The Impact of Trying Youth as Adults and Strategies for Reform (Washington: Campaign for Youth Justice, 2007). The authors cited two sources: Charles Puzzanchera and others, Office of Juvenile Justice and Delinquency Prevention, Juvenile Court Statistics 1999 (www.ncjrs.gov/pdffiles1/ojjdp/201241.pdf [July, 2003]), and Howard Snyder and Melissa Sickmund, National Center for Juvenile Justice, Juvenile Offenders and Victims: 1999 National Report (www.ncjrs.gov/html/ojjdp/nationalreport99/toc.html [September, 1999]).

45. See, for example, Kevin Strom and others, U.S. Department of Justice, Bureau of Justice Statistics, "Special Report," State Court Processing Statutes 1990-94, Juvenile Felony Defendants in Criminal Courts (www.ojp.gov/bjs/pub/pdf/jfdcc.pdf [September, 1998]).

46. But as juvenile drug arrests rose during the early part of the decade, the number of waived drug cases rose. Judicial waivers for drug offenses declined in number beginning in 1992, though the rate remained stable.

47. Snyder and Sickmund, Juvenile Offenders and Victims (see note 44), p. 236.

48. Ibid., p. 237.

49. Data were unavailable to determine whether those sentenced to prison were incarcerated in adult or juvenile facilities. See Campaign for Youth Justice, The Consequences Aren't Minor (see note 44), citing statistics from the California Board of Corrections and the California Department of Corrections.

50. This figure is cited, for example, in Campaign for Youth Justice, The Consequences Aren't Minor (see note 44), p. 21, note 4, quoting a 2005 report by the Coalition for Juvenile Justice, Childhood on Trial: The Failure of Trying and Sentencing Youth in Adult Criminal Court (www.appa-net.org/resources/pubs/docs/ CJJ-Report.pdf [2005]).

51. Donna M. Bishop, "The Role of Race and Ethnicity in Juvenile Justice Processing," in Our Children, Their Children: Confronting Racial and Ethnic Differences in American Juvenile Justice, edited by Darnell Hawkins and Kimberly Kempf-Leonard (University of Chicago Press, 2005).

52. See the article by Alex Piquero in this volume.

53. Kevin Strom, U.S. Department of Justice, Bureau of Justice Statistics, "Special Report," Profile of State Prisoners under Age 18, 1985-97 (http://ojp.usdoj.gov/bjs/pub/pdf/pspa1897.pdf [February, 2000]).

54. Campaign for Youth Justice, The Consequences Aren't Minor (see note 44). 
55. Puzzanchera and others, Juvenile Court Statistics 1999 (see note 44), p. 44.

56. Feld, Bad Kids (see note 6).

57. Bishop relied on the State Courts Processing System (SCPS), which includes all cases processed in the criminal courts and disaggregates by age.

58. Feld, Bad Kids (see note 6).

59. Janet Lauritsen's careful review of the evidence using multiple data sources to confirm patterns observed in arrest records suggests that offending rates for non-white youth may in fact be higher for violence and weapons charges, but not for drug crimes. See Janet Lauritsen, "Racial and Ethnic Differences in Juvenile Offending," in Our Children, Their Children, edited by Darnell Hawkins and Kimberly Kempf-Leonard (see note 51). This is important in the discussion of racial disparity, since drug crimes are one of the most commonly waived offenses for black youth, according to Snyder and Sickmund, Juvenile Offenders and Victims (see note 44), pp. 176, 187. Instead, Bishop, "The Role of Race and Ethnicity” (see note 51), suggests that racial disparities in police contacts and arrests per crime may be the case, based on strategic decisions about where and how to deploy police, and observed biases in police decision making. See also Bishop, "Juvenile Offenders in the Adult Criminal System" (see note 9). See, for example, Geoffrey Alpert, John MacDonald, and Roger Dunham, "Police Suspicion and Discretionary Decision Making during Citizen Stops," Criminology 43 (2005): 407-34. See also Jeffrey Fagan and Garth Davies, "Street Stops and Broken Windows: Race, Terry and Disorder in New York City," Fordham Urban Law Journal 28 (2000): 457.

60. Andrew Gelman, Jeffrey Fagan, and Alex Kiss, “An Analysis of the New York City Police Department's 'Stop-and-Frisk' Policy in the Context of Claims of Racial Bias," Journal of the American Statistical Association 102 (2007): 813-23.

61. Joshua Correll and others, "The Police Officer's Dilemma: Using Ethnicity to Disambiguate Potentially Threatening Individuals," Journal of Personality \& Social Psychology 83 (2002): 1314-29; Anthony G. Greenwald and others, "Targets of Discrimination: Effects of Race on Responses to Weapons Holders," Journal of Experimental Social Psychology 39 (2003): 399-405; E. Ashby Plant and B. Michelle Peruche, "The Consequences of Race for Police Officers' Responses to Criminal Suspects," Psychological Science 16 (2005):180-83; E. Ashby Plant and others, "Eliminating Automatic Racial Bias: Making Race NonDiagnostic For Responses to Criminal Suspects," Journal of Experimental Social Psychology 41 (2005): $141-56$.

62. For a thorough review of studies on racial profiling, sentencing, and police shootings, see R. Richard Banks, Jennifer L. Eberhardt, and Lee Ross, "Discrimination and Implicit Bias in a Racially Unequal Society," California Law Review 94 (2006): 1169-90. See also Sandra Graham and Brian S. Lowery, "Priming Unconscious Racial Stereotypes about Adolescent Offenders," Law \& Human Behavior 28 (2004): 483-504; George Bridges and Sara Steen, "Racial Disparities in Official Assessments of Juvenile Offenders: Attributional Stereotypes as Mediating Mechanisms,” American Sociological Review 63 (1998): $554-70$.

63. Jennifer Eberhardt and others, "Looking Deathworthy: Perceived Stereotypicality of Black Defendants Predicts Capital-Sentencing Outcomes," Psychological Science 17 (2006): 383-87; William Pizzi, Irene V. Blair, and Charles M. Judd, "Discrimination in Sentencing on the Basis of Afrocentric Features," Michigan Journal of Race and Law 10 (20075): 327-55. 
64. Roysher and Edelman, "Treating Juveniles as Adults in New York" (see note 11).

65. Feld, "The Juvenile Court Meets the Principle of the Offense" (see note 14); L. K. Gillespie and M. D. Norman, "Does Certification Mean Prison? Some Preliminary Findings from Utah," Juvenile and Family Court Journal 35 (1984): 23-34; and Dean J. Champion, "Teenage Felons and Waiver Hearings: Some Recent Trends, 1980-1988," Crime and Delinquency 35 (1989): 577-85.

66. See, for example, M. Houghtalin and G. L. Mays, "Criminal Dispositions of New Mexico Juveniles Transferred to Adult Court," Crime and Delinquency 37 (1991): 393-407; see also Charles W. Thomas and Shay Bilchik, "Prosecuting Juveniles in Criminal Courts: A Legal and Empirical Analysis," Journal of Criminal Law and Criminology 76 (1985): 439-79.

67. Peter W. Greenwood, Allan Abrahamse, and Franklin Zimring, Factors Affecting Sentencing Severity for Young Adult Offenders (Santa Monica, Calif.: Rand Corporation, 1984).

68. Barry C. Feld, "Violent Youth and Public Policy: A Case Study of Juvenile Justice Law Reform," Minnesota Law Review 79 (1995): 965-1128; Feld, Bad Kids (see note 6).

69. See Donna M. Bishop and others, "The Transfer of Juveniles to Criminal Court: Does It Make a Difference?" Crime and Delinquency 42 (1996): 171-91.

70. Aaron Kupchik, Jeffrey Fagan, and Akiva Liberman, "Punishment, Proportionality, and Jurisdictional Transfer of Adolescent Offenders: A Test of the Leniency Gap Hypotheses," Stanford Law and Policy Review 14 (2003): 57-83. See also Simon Singer, Jeffrey Fagan, and Akiva Liberman, "The Reproduction of Juvenile Justice in Criminal Court: A Case Study of New York's Juvenile Offender Law," in Changing Borders of Juvenile Justice, eds. Fagan and Zimring (see note 7).

71. Kupchik, Fagan, and Liberman, "Punishment, Proportionality, and Jurisdictional Transfer" (see note 70).

72. See Patricia Torbet and others, State Responses to Serious and Violent Juvenile Crime (see note 23); Melissa Sickmund, Office of Juvenile Justice and Delinquency Prevention, “OJJDP Update on Statistics," How Juveniles Get to Criminal Court (www.ncjrs.gov/pdffiles/juvcr.pdf [October, 1994]); Feld, Bad Kids (see note 6).

73. Cary S. Rudman, Jeffrey Fagan, and Eliot C. Hartstone, "Violent Youth in Adult Court: Process and Punishment," Crime and Delinquency 32 (1986): 75-96.

74. Feld and Podkopacz, "The End of the Line" (see note 21), studying 1986-1992 waiver in Hennepin County, Minnesota.

75. Fagan, "Separating the Men from the Boys" (see note 27).

76. Martin A. Forst, Jeffrey Fagan, and T. Scott Vivona, "Some Paradoxical Effects of the Treatment-Custody Dichotomy for Adolescents in Adult Prisons," Juvenile and Family Court Journal 40 (1989): 1-15.

77. Evidently, the success of waiver reform, which would return children to the juvenile court, depends on confidence in the programs of the juvenile court. Peter W. Greenwood, Changing Lives: Delinquency Prevention as Crime-Control Policy (Chicago University Press, 2006).

78. Data on file with author.

79. However, some criminologists, such as William Spelman, believe that there may be incapacitation effects from imprisonment, where active offenders are locked up and unable to commit new crimes on the 
streets, but that few would-be offenders are deterred from crime by the threat of incarceration. See, for example, William Spelman, "The Limited Importance of Prison Expansion," in The Crime Drop in America, edited by Alfred Blumstein and Joel Wallman (Cambridge University Press, 2000).

80. Among inmates released between age eighteen and twenty-four, 75.4 percent were rearrested within three years, 52.0 percent were re-convicted, and 52.0 percent were returned to prison. Among inmates aged fourteen to seventeen at release, the rates were higher: 82.1 percent rearrested, 55.7 percent reconvicted, and 56.6 percent returned to prison. Patrick Langan and David Levin, U.S. Department of Justice, Bureau of Justice Statistics, "Special Report," Recidivism of Prisoners Released in 1994 (www.ojp. usdoj.gov/bjs/pub/pdf/rpr94.pdf [June, 2002]).

81. Robert J. Sampson and John H. Laub, Crime in the Making: Pathways and Turning Points through Life (Harvard University Press, 1993); Richard Freeman, "Why Do So Many Young American Men Commit Crimes and What Might We Do about It?” Journal of Economic Perspectives 10, no. 1 (1996): 25-42.

82. Simon I. Singer and David McDowall, "Criminalizing Delinquency: The Deterrent Effects of the New York Juvenile Offender Law," Law and Society Review 22, no. 3 (1988): 521-36.

83. Barry Glassner and others, "A Note on the Deterrent Effect of Juvenile vs. Adult Jurisdiction," Social Problems 31, no. 2 (1983): 219-21. According to Singer, Recriminalizing Delinquency (see note 6), brochures were sent to public schools announcing the new law and its harsh consequences, and juvenile court judges routinely issued warnings about the serious punishment that awaited anyone who violated the new law. Paul H. Robinson and John M. Darley, "Does Criminal Law Deter? A Behavioural Science Investigation," Oxford Journal of Criminal Law 24 (2004): 173-205.

84. E. L. Jensen and L. K. Metsger, "A Test of the Deterrent Effect of Legislative Waiver on Violent Juvenile Crime," Crime \& Delinquency 40, no. 1 (January 1994): 96.

85. Robert Barnowski, "Changes in Washington State's Jurisdiction of Juvenile Offenders: Examining the Impact," available at www.wsipp.wa.gov/rptfiles/JuvJurisChange.pdf (2003).

86. Steven D. Levitt, “Juvenile Crime and Punishment," Journal of Political Economy 106 (1998): 1156-85.

87. David Lee and Justin McCrary, "Crime, Punishment, and Myopia," Working Paper W11491 (Cambridge, Mass.: National Bureau of Economic Research, 2005), available at http://ssrn.com/abstract=762770.

88. Ibid. See also Jonathan Gruber, Risky Behavior among Youth: An Economic Analysis (University of Chicago Press, 2001).

89. Lee and McCrary, "Crime, Punishment, and Myopia” (see note 87).

90. McGowan and others, "Effects on Violence" (see note 9). The committee standardized published results of transfer studies by computing point estimates for the relative change in the violent crime rates attributable to the interventions. The reviewers calculated baselines and percent changes using the following formulas for relative change. For studies with before-and-after measurements and concurrent comparison groups, the effect size was computed as:

where:

$$
\text { (Ipost/Ipre)/(Cpost/Cpre) }-1
$$

Ipost $=$ the last reported outcome rate in the intervention group after the intervention; Ipre $=$ the reported outcome rate in the intervention group before the intervention; Cpost $=$ the last reported outcome rate in the comparison group after the intervention; 
Cpre $=$ the reported outcome rate in the comparison group before the intervention .

If modeled results were reported from logistic regressions, odds ratios were adjusted for comparability to relative rate changes estimated from other studies:

where:

$$
R R=O R /\left(\left[1-P_{0}\right]+\left[P_{0} \times O R\right]\right)
$$

$R R=$ relative risk;

$O R=$ odds ratio to be converted;

$P 0=$ incidence of the outcome of interest in the unexposed population (that is, juveniles retained in the juvenile justice system).

91. See McGowan and others, "Effects on Violence" (see note 9), for specific citations of studies included in their analysis.

92. In a subsequent study, Fagan, Kupchik, and Liberman used a similar design with more counties and an expanded list of sampled offenses. Jeffrey Fagan, Aaron Kupchik, and Akiva Liberman, "Be Careful What You Wish for: Legal Sanctions and Public Safety among Adolescent Offenders in Juvenile and Criminal Court," Columbia Law School, Public Law Research Paper no. 03-61 (available at SSRN: http://ssrn. com/abstract=491202 [July, 2007]). Their results were similar to the Fagan study, "Separating the Men from the Boys" (see note 27). The more recent study was not included in the Task Force analysis, which included only published studies.

93. See Fagan, "Separating the Men from the Boys" (see note 27); Fagan, Kupchik, and Liberman, "Be Careful What You Wish for" (see note 91); Bishop and others, "The Transfer of Juveniles to Criminal Court" (see note 69).

94. John C. Hagan and Kristin Bumiller, Making Sense of Sentencing: A Review and Critique of Sentencing Research, vol. 2 in Research on Sentencing: The Search for Reform, edited by Alfred Blumstein and others (Washington: National Academy Press, 1983), pp. 1-54; see also Charles R. Tittle, Sanctions and Social Deviance: The Question of Deterrence (New York: Praeger, 1980); Charles R. Tittle, "Evaluating the Deterrent Effects of Criminal Sanctions," in Handbook of Criminal Justice Evaluation, edited by Malcolm Klein and Kathie Teilmann (Beverly Hills, Calif.: Sage Publications, 1980).

95. Lawrence Winner and others, "The Transfer of Juveniles to Criminal Court: Reexamining Recidivism Over the Long Term," Crime and Delinquency 43 (1997): 548-63. The criteria were: (1) most serious offense for which the transfer was made, (2) the number of counts included in the bill of information for the committing offense, (3) the number of prior referrals to the juvenile court, (4) the most serious prior offense, (5) age at the time of committing the offense, (6) gender, and (7) race (coded dichotomously as white or non-white).

96. Paul R. Rosenbaum and Donald B. Rubin, "Reducing Bias in Observational Studies Using Subclassification on the Propensity Score," Journal of the American Statistical Association 79 (1984): 516-24.

97. Lonn Lanza-Kaduce and others, Florida Department of Juvenile Justice, Juvenile Transfer to Criminal Court Study: Final Report (www.prisonpolicy.org/scans/juveniletransfers.pdf [January, 2002]).

98. Fagan, "Separating the Men from the Boys" (see note 27); Fagan, Kupchik, and Liberman, "Be Careful What You Wish for" (see note 91).

99. The identification task to estimate propensity scores requires the selection of variables that approximate the matrix of information available to judges or prosecutors and the logic they use in deciding whether 
to transfer. The selection or propensity models estimated when researchers lack full information that is available to judges or prosecutors may be artifactual at best and, under extreme conditions, inaccurate. See, for example, Randall Salekin and others, "Juvenile Transfer to Adult Courts: A Look at Prototypes for Dangerousness, Sophistication-Maturity, and Amenability to Treatment through a Legal Lens," Psychology, Public Policy, and Law 8, no. 4 (2002): 373-410; D. N. Brannen and others, "Transfer to Adult Court: A National Study of How Juvenile Court Judges Weigh Pertinent Kent Criteria," Psychology, Public Policy, and Law (forthcoming).

100. Bishop and Frazier, "Consequences of Transfer," in The Changing Borders of Juvenile Justice, edited by Fagan and Zimring (see note 7); Bishop, "Juvenile Offenders in the Adult Criminal System” (see note 9).

101. Richard E. Redding, "The Effects of Adjudicating and Sentencing Juveniles as Adults," Youth Violence and Juvenile Justice 1, no. 2 (2003): 128-55.

102. David O. Brink, "Immaturity, Normative Competence, and Juvenile Transfer: How (Not) to Punish Minors for Major Crimes," Texas Law Review 82 (2004): 1555-85.

103. Elizabeth F. Emens, "Aggravating Youth: Roper v. Simmons and Age Discrimination," Supreme Court Review 2005: 51-102.

104. Lawrence Bobo and Devon Johnson, “A Taste for Punishment: Black and White Americans' Views on the Death Penalty and the War on Drugs," Du Bois Review 1 (2004): 151-80.

105. North Carolina is one of the nation's two remaining states that set the age of majority for criminal responsibility at sixteen. Connecticut legislators used the study commission model to create political space for reform and to build consensus among stakeholders during the three-year planning process.

106. Even as juvenile crime rates had begun their decade-long decline, inaccurate facts were cited to militate for yet tougher measures. For example, Representative Bill McCollum, chair of the House Subcommittee on Crime in the 106th Congress, argued for tougher transfer laws by stating that "in America, no population poses a greater threat to public safety than juvenile offenders." House Committee on the Judiciary, Putting Consequences Back into Juvenile Justice at the Federal, State, and Local Levels: Hearings before the Subcommittee on Crime, 106th Congress, 1999, p. 5.

107. Carl F. Cranor, Regulating Toxic Substances: A Philosophy of Science and the Law (Oxford University Press, 1993).

108. See Zimring and Fagan, "Transfer Policy and Law Reform," in The Changing Borders of Juvenile Justice, edited by Fagan and Zimring (see note 7). See also "Fagan, "Separating the Men from the Boys" (see note 27); Fagan, Kupchik, and Liberman, "Be Careful What You Wish for" (see note 91)"; Feld and Podkopacz, “The Back-Door to Prison” (see note 19).

109. Katherine Beckett, Making Crime Pay: Law and Order in Contemporary American Politics (Oxford University Press, 1997).

110. See Bishop, "Juvenile Offenders in the Adult Criminal System" (see note 9). 